\title{
Autotrophic picoplankton in mesozooplankton guts: evidence of aggregate feeding in the mesopelagic zone and export of small phytoplankton
}

\author{
S. E. Wilson ${ }^{1, *}$, D. K. Steinberg ${ }^{2}$ \\ ${ }^{1}$ Monterey Bay Aquarium Research Institute, 7700 Sandholdt Road, Moss Landing, California 95039, USA \\ ${ }^{2}$ Virginia Institute of Marine Science, College of William and Mary, Route 1208 Greate Road, \\ Gloucester Point, Virginia 23062, USA
}

\begin{abstract}
Zooplankton play a key role in affecting the efficiency by which organic matter is exported to depth. Mesozooplankton consumption of detrital aggregates has been hypothesized as a mechanism for enhancing the export of picoplankton from surface layers. We analyzed the gut contents of mesopelagic copepods and ostracods using light and epifluorescence microscopy to determine if cyanobacteria and eukaryotic phytoplankton too small to be ingested individually were present. Hind-guts were dissected from multiple species collected in discrete depth intervals between 0 and $1000 \mathrm{~m}$ during the day and night, at contrasting sites in the subtropical (Hawaii Ocean Timeseries site ALOHA) and subarctic (Japanese time-series site K2) Pacific Ocean. Autofluorescing cyanobacteria and small eukaryotic phytoplankton were found in the guts of nearly all species sampled from all depths, indicating consumption of aggregates. Some of the cyanobacteria and other small cells ingested may have originated from inside the guts, or as symbionts, of microzooplankton, which were also common in the guts of many of these species. At both sites, most species' guts contained higher concentrations of cyanobacteria and small phytoplankton at night than during the day. Ostracod guts at ALOHA contained higher densities of picoplankton than those at K2, reflecting the predominance of smaller cells at ALOHA. Guts of diel vertical migrators still contained picoplankton at their deep, daytime residence depths, indicating active export of these cells. Our results indicate mesozooplankton grazing on aggregates is a pathway by which flux of picoplankton can be enhanced.
\end{abstract}

KEY WORDS: Zooplankton · Gut contents $\cdot$ Cyanobacteria $\cdot$ Picoplankton $\cdot$ Marine snow $\cdot$ Biological pump $\cdot$ Mesopelagic zone $\cdot$ Diel vertical migration

\section{INTRODUCTION}

The trophic ecology of the mesopelagic zooplankton community plays an important role in affecting the flux of particulate organic matter to the deep sea (Noji 1991, Lampitt 1992, Jackson 1993, Sarnelle 1999). Zooplankton residing in the mesopelagic zone (base of the euphotic zone to $1000 \mathrm{~m}$ ) must obtain their nutrition via feeding on sinking aggregates (including fecal pellets and detrital material), vertical migration to the surface, or carnivory (Angel 1989, Steinberg et al. 2000,
Schnetzer \& Steinberg 2002b). While all of these processes help to determine the efficiency of the biological pump, studies of the feeding ecology of midwater organisms are limited. In particular, feeding on sinking aggregates of detritus ('marine snow') is difficult to quantify, but is assumed to be widespread (e.g. Dagg 1993, Lampitt et al. 1993, Dilling et al. 1998, Dilling \& Brzezinski 2004).

A better understanding of mesopelagic food webs is thus needed to determine how zooplankton affect particle flux and carbon transport. There are only a hand- 
ful of studies of the diets of mesopelagic zooplankton, and microscopy has been used to identify phytoplankton tests, crustacean carapaces, and detritus in their guts (e.g. Nishida et al. 1991, Uttal \& Buck 1996, Kosobokova et al. 2002, Schnetzer \& Steinberg 2002b). Previous studies have indicated that a large proportion of zooplankton gut content is detrital in origin (Steinberg 1995, Kosobokova et al. 2002, Schnetzer \& Steinberg 2002b). For example, gut contents of the Antarctic mesopelagic copepod Spinocalanus antarcticus were almost entirely comprised of detritus balls (Kosobokova et al. 2002). Mesopelagic copepods associated with larvacean mucous feeding webs ('houses') had fragments of diatoms, microzooplankton, fecal pellets, and pieces of the mucous web in their gut (Steinberg 1995). Guts of diel vertically migrating (DVM) zooplankton in the Sargasso Sea near Bermuda also contained items indicative of feeding on marine snow (Schnetzer \& Steinberg 2002b).

Marine snow aggregates contain phytoplankton, bacteria, and cyanobacteria, and the concentration of picoplankton in aggregates may be orders of magnitude higher than that in surrounding seawater (Alldredge \& Silver 1988, Lochte \& Turley 1988, Waite et al. 2000, Zhang et al. 2008). Free-living picoplankton are too small to be individually captured by mesozooplankton other than filter and mucous web feeders, such as salps and larvaceans (e.g. Nival \& Nival 1976, Silver \& Bruland 1981, Lampitt et al. 1993, Pfannkuche \& Lochte 1993). Thus, high densities of cyanobacteria such as Synechococcus spp. occurring in the gut and fecal pellets of mesozooplankton are a good indicator of detritivory (Nishida et al. 1991, Pfannkuche \& Lochte 1993, Schnetzer \& Steinberg 2002b). There is also evidence that picoplanktonic cyanobacteria may be resistant to digestion by zooplankton, as viable cells have been observed in fecal pellets and deep-sea sediments (Silver \& Alldredge 1981, Lampitt et al. 1993, Turner 2002 and references therein).

Recent studies suggest that autotrophic picoplankton, through aggregation and subsequent grazing by mesozooplankton, may make a larger contribution to export flux than previously thought (Richardson et al. 2004, Richardson \& Jackson 2007). In the equatorial Pacific, 61 to $76 \%$ of picoplankton net primary production is estimated to contribute to particulate organic carbon (POC) flux out of the euphotic zone via mesozooplankton (Richardson et al. 2004). Inverse modeling indicates that the largest contribution to export of these small cells is via grazing of aggregates and picoplankton-fed microzooplankton by larger zooplankton, and that carbon export of small cells via mesozooplankton grazing pathways may be up to 10 times higher than via direct picoplankton export (in aggregates, Richardson et al. 2004, Richardson \& Jack- son 2007). Support for these assertions includes the discovery of Synechococcus-like cyanobacteria in abundance in bathypelagic sediment traps, fecal pellets, and in abyssal sea-floor sediments (Silver et al. 1986, Lochte \& Turley 1988, Lampitt et al. 1993, Pfannkuche \& Lochte 1993).

Furthermore, $\mathrm{N}_{2}$-fixing (diazotrophic) colonial cyanobacteria such as Trichodesmium spp., endosymbiotic Richelia spp., and newly discovered 3 to $10 \mu \mathrm{m}$ picoplanktonic nitrogen fixers have recently been determined to be food sources for zooplankton in tropical and subtropical regions through $\delta^{15} \mathrm{~N}$ measurements (Zehr et al. 2001, Montoya et al. 2002, Montoya et al. 2004). The ingestion of diazotrophs by zooplankton is an important but little-studied pathway by which fixed nitrogen is incorporated into higher trophic levels, and is of interest to the present study as a mechanism by which new nitrogen may be transported to depth (Carpenter \& Capone 2008).

In this study, we investigated the role that mesopelagic zooplankton play in consumption and export of small phytoplankton by quantifying picoplankton (and other visible food items) in the guts of copepods and ostracods at depths ranging from the surface to $1000 \mathrm{~m}$. This study was part of a larger project investigating the controls on particle flux through the mesopelagic zone in the subtropical (Hawaii Ocean Time-series site ALOHA) and subarctic (Japanese time-series site K2) North Pacific Ocean (VERtical Transport In the Global Ocean, VERTIGO, Buesseler et al. 2007, Steinberg et al. 2008b). These data not only characterize mesopelagic food webs in 2 contrasting environments, but also allow us to test hypothesized mechanisms for the export of small cells to depth and how picoplankton flux may contribute to the biological pump.

\section{MATERIALS AND METHODS}

Sample collection. Zooplankton samples were collected at the Hawaii Ocean Time-series (HOT) station ALOHA in the oligotrophic N Pacific subtropical gyre $\left(27.75^{\circ} \mathrm{N}, 158^{\circ} \mathrm{W}\right)$ from 22 June to 9 July 2004 aboard the RV 'Kilo Moana', and at the Japan Agency for Marine-Earth Science and Technology (JAMSTEC) time-series site K2, in a high nutrient, variable chlorophyll region of the $\mathrm{N}$ Pacific subarctic gyre $\left(47^{\circ} \mathrm{N}\right.$, $160^{\circ} \mathrm{E}$ ) from 22 July to 11 August 2005 aboard the RV 'Roger Revelle'. Environmental parameters at the 2 sites differed, including water column-integrated net primary production (ALOHA: 180 to $220 \mathrm{mg} \mathrm{C} \mathrm{m}^{-2} \mathrm{~d}^{-1}$, $\mathrm{K} 2: 302$ to $603 \mathrm{mg} \mathrm{C} \mathrm{m}^{-2} \mathrm{~d}^{-1}$ ), new production (ALOHA: 18 to $38 \mathrm{mg} \mathrm{C} \mathrm{m}^{-2} \mathrm{~d}^{-1}, \mathrm{~K} 2: 70$ to $150 \mathrm{mg} \mathrm{C} \mathrm{m}^{-2} \mathrm{~d}^{-1}$ ) and mixed layer nutrients (ALOHA: nanomolar concentra- 
tions, K2: $12 \mu \mathrm{M}$ dissolved inorganic nitrogen, Boyd et al. 2008, Buesseler et al. 2008, Elskens et al. 2008, Lamborg et al. 2008, Zhang et al. 2008). The phytoplankton assemblage consisted of small diatoms, dinoflagellates, coccolithophorids, picoplankton and cyanobacteria at ALOHA and picoplankton and large diatoms at K2 (Boyd et al. 2008, Lamborg et al. 2008, Zhang et al. 2008). Paired day/night tows were conducted at 9 discrete depth intervals $(0-50,50-100,100-150$, 150-200, 200-300, 300-400, 400-500, 500-750, and $750-1000 \mathrm{~m}$ ) using a $1 \mathrm{~m}^{2}, 335 \mu \mathrm{m}$ mesh MOCNESS (Multiple Opening/Closing Net and Environmental Sensing System, Wiebe et al. 1985) and IONESS (Intelligent Operative Net Sampling System, Buesseler et al. 2007, Steinberg et al. 2008a) with filtering cod-end buckets.

A total of 4 paired day/night tows were conducted at each location and 1 set of paired tows from ALOHA and K2 were split to collect zooplankton for this study (see methods in Steinberg et al. 2008a). At ALOHA, where net primary production was uniform during our sampling period (Boyd et al. 2008), the third day/night cast (3 to 4 July 2004) was randomly selected for this study. At K2, net primary production decreased during our sampling period (Boyd et al. 2008, Buesseler et al. 2008) and the first set of day/night tows (31 July to
1 August 2005), taken before the bloom diminished, was selected to provide maximum contrast between the 2 sites.

Upon net recovery (time from animal capture at a given depth to net retrieval ranged from $\sim 3 \mathrm{~min}$ to $2 \mathrm{~h}$, Table 1), the cod-ends were removed and stored in buckets in an air-conditioned laboratory at ALOHA and at ambient air temperature at K2 before processing (Table 1). Although there is little in the literature citing evidence for artifacts from cod-end/bucket feeding in mesopelagic zooplankton (e.g. Hopkins 1985), we acknowledge the possibility and steps were taken during both processing and analyses to minimize their impact on the results. Most animals selected for gut content analysis were large calanoid copepod species with long gut passage times (1.5 to $>3 \mathrm{~h}$; Dagg \& Wyman 1983, Schnetzer \& Steinberg 2002a and references therein), their foreguts were removed as a precaution and excluded from analysis (see below), replicate analyses were made for each species when possible, and no animals were selected from 750-1000 $\mathrm{m}$ at ALOHA (the longest duration animals would have been in the net, Table 1). To avoid increased gut evacuation rates due to temperature changes experienced by the zooplankton (Dagg \& Wyman 1983, Irigoien 1998 and references therein),

Table 1. Environmental variables related to the collection of zooplankton at the stations ALOHA and K2. Data presented include the approximate temperature $\left({ }^{\circ} \mathrm{C}\right)$ in which the zooplankton in buckets were held both before and during processing, the maximum time $(\mathrm{h})$ of processing of all the buckets, the average water temperature $\left({ }^{\circ} \mathrm{C}\right)$ at each depth interval, the duration (min) animals were in the nets during their ascent through the water column, the total number (no.) of animals selected for analysis at each depth, and the percentage (\%) of the total animals analyzed that contained material in their guts. ${ }^{*}$ Actual time was not recorded but was slightly longer than processing times at ALOHA. na = not available; w/ = with

\begin{tabular}{|c|c|c|c|c|c|c|c|c|}
\hline $\begin{array}{l}\text { Depth } \\
\text { interval (m) }\end{array}$ & $\begin{array}{l}{ }^{\circ} \mathrm{C} \text { at } \\
\text { depth }\end{array}$ & $\begin{array}{c}\text { Duration } \\
\text { in net (min) }\end{array}$ & $\begin{array}{c}\text { Total no. } \\
\text { animals selected }\end{array}$ & $\begin{array}{l}\% \text { w/food } \\
\text { in gut }\end{array}$ & $\begin{array}{l}{ }^{\circ} \mathrm{C} \text { at } \\
\text { depth }\end{array}$ & $\begin{array}{c}\text { Duration } \\
\text { in net (min) }\end{array}$ & $\begin{array}{c}\text { Total no. } \\
\text { animals selected }\end{array}$ & $\begin{array}{c}\% \text { w/food } \\
\text { in gut }\end{array}$ \\
\hline ALOHA & \multicolumn{4}{|c|}{$\longrightarrow$ Day $\left(22^{\circ} \mathrm{C}_{\mathrm{r}}<2 \mathrm{~h}\right)$} & \multicolumn{4}{|c|}{ Night $\left(22^{\circ} \mathrm{C},<2.8 \mathrm{~h}\right)$} \\
\hline $0-50$ & 26.3 & 7.6 & 28 & 36 & 26.2 & 8.8 & 48 & 71 \\
\hline $50-100$ & 24.5 & 19.2 & 42 & 41 & 24.7 & 18.6 & 87 & 57 \\
\hline $100-150$ & 22.5 & 27.1 & 20 & 55 & 23.0 & 31.6 & 59 & 68 \\
\hline $150-200$ & 20.7 & 35.6 & 23 & 65 & 20.8 & 40.0 & 16 & 63 \\
\hline $200-300$ & 16.6 & 53.7 & 42 & 29 & 15.6 & 60.7 & 12 & 67 \\
\hline $300-400$ & 10.9 & 68.2 & 28 & 39 & 11.3 & 73.8 & 25 & 40 \\
\hline $400-500$ & 8.6 & 80.9 & 93 & 45 & 8.4 & 85.8 & 18 & 67 \\
\hline $500-750$ & 5.9 & 103.8 & 31 & 48 & 5.9 & 111.3 & 13 & 38 \\
\hline $750-1000$ & 4.4 & 125.0 & 0 & na & 4.4 & 131.3 & 0 & na \\
\hline K2 & \multicolumn{4}{|c|}{$\operatorname{Day}\left(11.1^{\circ} \mathrm{C},<3 \mathrm{~h}^{*}\right)$} & \multicolumn{4}{|c|}{ Night $\left(11.4^{\circ} \mathrm{C}_{1}<3 \mathrm{~h}^{*}\right)$} \\
\hline $0-50$ & 7.4 & 3.1 & 22 & 95 & 8.5 & 9.2 & 43 & 93 \\
\hline $50-100$ & 2.1 & 6.1 & 27 & 52 & 2.3 & 14.2 & 61 & 89 \\
\hline $100-150$ & 1.9 & 9.8 & 30 & 13 & 1.6 & 19.6 & 53 & 62 \\
\hline $150-200$ & 2.8 & 16.6 & 61 & 21 & 2.5 & 19.1 & 63 & 54 \\
\hline $200-300$ & 3.1 & 17.7 & 69 & 25 & 3.1 & 32.3 & 54 & 24 \\
\hline $300-400$ & 3.3 & 24.3 & 90 & 48 & 3.3 & 42.6 & 54 & 30 \\
\hline $400-500$ & 3.2 & 33.1 & 94 & 43 & 3.2 & 52.0 & 102 & 23 \\
\hline $500-750$ & 3.1 & 49.2 & 40 & 13 & 3.1 & 70.7 & 71 & 16 \\
\hline $750-1000$ & 2.8 & 67.1 & 52 & 17 & 2.7 & 94.4 & 59 & 14 \\
\hline
\end{tabular}


processing times were kept to a minimum and the nets that had the longest tow durations and therefore the largest disparity in temperature were dealt with first (Table 1).

Samples from each depth/cod end were divided using a Folsom plankton splitter and splits (1/8 to 1/16 of whole sample) were flash frozen in liquid nitrogen and stored at $-80^{\circ} \mathrm{C}$ until analysis. Remaining sample aliquots were used for analysis of size fractionated biomass, lipid biomarkers, and enumeration of taxa (Kobari et al. 2008, Steinberg et al. 2008a, Wilson et al. 2010).

Sample analysis. Frozen samples were thawed the day of their analysis and immediately sorted for target zooplankton species while kept cold and in the dark. At both sites, several calanoid copepod genera and miscellaneous ostracods were selected from each sample depth at which they were present. Target species were selected based on hypothesized diet, vertical migration patterns, and large size. At ALOHA, the copepod species analyzed were: Pleuromamma xiphias, P. piseki/ gracilis (grouped together), P. abdominalis, Neocalanus robustior, Paraeucalanus attenuatus, Lucicutia sp., Euchaeta rimana and miscellaneous large calanoid copepods (>3 mm). At K2, the target copepod species were: $N$. cristatus, $N$. plumchrus and Eucalanus bungii (which are abundant, ontogenetic vertical migrators, Kobari et al. 2008), Paraeuchaeta spp., Metridia pacifica, and $P$. quadrangulata. Ostracods were not individually identified to species, but both stations contained members of the genera Conchoecia and Porroecia (Steinberg et al. 2008a). At both sites, usually $\geq 10$ individuals of each taxa per depth interval were examined for visible gut contents, although some depths at both sites contained $\leq 10$ individuals of a given taxa (Steinberg et al. 2008a).

Replicates of each species present at each location, depth interval, and time (day and night) were sorted into a multi-welled petri dish placed on ice and filled with filtered seawater. Before dissection, specimens were photographed using an Olympus SZX12 stereo dissecting microscope and Olympus DP71 digital camera, and the presence or absence of gut contents was noted. Up to 5 individuals (if available) from each taxon with visible gut contents were then dissected on a microscope slide. Gut contents of both Neocalanus species, Eucalanus bungii, and Paraeuchaeta spp. at K2 were only analyzed from day samples; for the remaining target species both day and night samples were analyzed. To exclude the foregut and obtain the mid- and lower gut for analysis, the upper cephalosome of the copepods was removed with fine sharpened microdissecting probes, leaving the rest of the body (below all mouthpart appendages) and the lower $2 / 3$ of the gut. The remaining gut was photographed and measured on the dissection microscope, and the volume of gut containing material was calculated using the formula for the volume of a cylinder for copepods, and an ovoid for ostracods. Samples were smeared on the slide with a probe, and autofluorescing cells were analyzed using a Nikon Labophot-2 epifluorescence microscope under blue (510 to $560 \mathrm{~nm}$ ) and green (450 to $490 \mathrm{~nm}$ ) excitation filters, and under normal transmitted light. All samples were photographed with the same digital camera system described above, and Imagepro and Adobe Photoshop software were used to enumerate and measure phytoplankton cells and other items in the guts. Red (chl a-containing eukaryotic phytoplankton) and yellow (phycoerythrin- and phycocyanin-containing cyanobacteria) autofluorescing cells were enumerated under blue or green light. Other recognizable gut contents, such as shells, microzooplankton, and crustacean parts, were also enumerated.

Data for cyanobacteria and eukaryotic phytoplankton are reported as the number of cells per cubic millimeter (cells $\mathrm{mm}^{-3}$ ) of gut material. For guts containing high densities or large clusters of cyanobacteria cells (see Fig. 1A,B), cell numbers were estimated using the Imagepro 'count and measure' function or by counting the cells within a smaller area and extrapolating to total area of gut material. Yellow-fluorescing cyanobacteria cells were categorized as small (1 to $5 \mu \mathrm{m}$ in diameter) and large ( $>5 \mu \mathrm{m}$ in diameter) size classes. The yelloworange fluorescing algal cryptophytes are also included in the latter category. The 1 to $5 \mu \mathrm{m}$ cells likely include Synechococcus spp. at both sites, and Richelia spp. and small unicellular diazotrophs at ALOHA (M. W. Silver pers. comm., Zehr et al. 2001, 2007, Montoya et al. 2004). The $>5 \mu \mathrm{m}$ category likely includes single cells from Trichodesmium spp. trichomes (ALOHA), unicellular diazotrophs (ALOHA), and cryptophytes (both sites) (M. W. Silver pers. comm., Zehr et al. 2001, 2007, Montoya et al. 2004). Only intact red fluorescing cells $>3 \mu \mathrm{m}$ were enumerated. The predominant eukaryotic algae were pennate and centric diatoms, and dinoflagellates; however, amorphous red-pigmented material was common in ostracods and in zooplankton that had consumed foraminiferans (e.g. symbionts that were visible inside mixotrophic foraminifera) and were not included in the red cell counts. Tiny $(<1 \mu \mathrm{m})$ red-fluorescing cells, presumably Prochlorococcus spp., were not enumerated in this study.

\section{RESULTS}

\section{Proportion of zooplankton with gut contents}

The proportion of zooplankton individuals with visible gut contents varied by taxa at both ALOHA and K2 (Table 2). At ALOHA, it ranged from $34 \%$ (epipelagic 
Table 2. Target zooplankton species at ALOHA and K2 collected from 0 to $1000 \mathrm{~m}$ Data are presented for percentage (\%) of the total number of species from all depths containing: any food in their guts, cyanobacteria (cyano) in 2 different size classes, and eukaryotic phytoplankton (phyto) $>2 \mu \mathrm{m}$. Carapace length (CL) mean $\pm \mathrm{SE}$, from tip of rostrum to the end of metasome (prosome length) for copepods or dorsal valve length for ostracods. For ALOHA, $n=11$ to 137 total individuals of each target group examined for visible gut contents, and $n=8$ to 67 individuals of each target group for guts that contained material. For K2, n = 31 to 146 individuals examined for visible gut contents, and $\mathrm{n}=7$ to 61 for guts that contained material. w/ $=$ with, misc. $=$ miscellaneous, $\lg .=$ large

\begin{tabular}{|lccccc|}
\hline & $\begin{array}{c}\mathrm{CL} \\
(\mathrm{mm})\end{array}$ & $\begin{array}{c}\text { \%w/ } \\
\text { food }\end{array}$ & $\begin{array}{c}\text { \%w/cyano } \\
(1-5 \mu \mathrm{m})\end{array}$ & $\begin{array}{c}\text { \% } \\
(>5 \mu \mathrm{m}) \\
(>2 \mu \mathrm{m})\end{array}$ \\
\hline ALOHA target groups & & & & & \\
Euchaeta rimana & $2.0 \pm 0.3$ & 34 & 86 & 82 & 77 \\
Lucicutia sp. & $0.9 \pm 0.0$ & 36 & 50 & 100 & 100 \\
Neocalanus robustior & $2.2 \pm 0.2$ & 37 & 83 & 89 & 67 \\
Paraeucalanus attenuatus & $2.8 \pm 0.4$ & 38 & 93 & 93 & 71 \\
Pleuromamma abdominalis & $2.2 \pm 0.1$ & 50 & 100 & 93 & 86 \\
Pleuromamma piseki/gracilis & $1.3 \pm 0.1$ & 39 & 100 & 88 & 88 \\
Pleuromamma xiphias & $2.5 \pm 0.4$ & 79 & 100 & 95 & 82 \\
misc. lg. calanoids & $3.1 \pm 0.8$ & 82 & 89 & 100 & 89 \\
misc. ostracods & $1.2 \pm 0.2$ & 91 & 98 & 88 & 83 \\
K2 target groups & & & & & \\
Eucalanus bungii & $5.1 \pm 0.7$ & 33 & 100 & 63 & 63 \\
Metridia pacifica & $2.5 \pm 0.2$ & 57 & 100 & 60 & 83 \\
Neocalanus cristatus & $7.2 \pm 0.2$ & 47 & 100 & 86 & 100 \\
Neocalanus plumchrus & $4.1 \pm 0.2$ & 17 & 100 & 70 & 80 \\
Paraeuchaeta spp. & $3.7 \pm 0.7$ & 51 & 93 & 36 & 43 \\
Pleuromamma quadrangulata & $2.6 \pm 0.1$ & 89 & 100 & 71 & 78 \\
misc. ostracods & $1.2 \pm 0.1$ & 75 & 98 & 49 & 61 \\
\hline
\end{tabular}

species Euchaeta rimana) to $91 \%$ (ostracods, Table 2), and at K2 from $17 \%$ (Neocalanus plumchrus) to $89 \%$ (Pleuromamma quadrangulata, Table 2). Identifiable gut material at both locations included cyanobacteria, eukaryotic phytoplankton (e.g. centric and pennate diatoms, dinoflagellates), foraminiferans, radiolarians, gastropod shells, tintinnid lorica, and crustacean carapace fragments (Fig. 1A-E).

For zooplankton residing primarily in the upper $150 \mathrm{~m}$ at ALOHA (Euchaeta rimana, Neocalanus robustior, and Paraeucalanus attenuatus), the proportion of guts with food was significantly higher at night (mean $\pm \mathrm{SE}=45 \pm$ $13 \%$, range 18 to $100 \%$, 0 to $150 \mathrm{~m})$ than day ( $28 \pm 11 \%$, range 0 to $50 \%$, Mann-Whitney test, p < 0.05; Fig. 2A). The percentage of DVM copepods (e.g. Pleuromamma abdominalis, $P$. piseki/gracilis, and $P$. xiphias) containing food in their guts was also higher at night while in the epipelagic zone (mean $\pm \mathrm{SE}=83 \pm 10 \%$, range 56 to $100 \%, 0$ to $150 \mathrm{~m}$ ) than during the day while in the mesopelagic zone $(23 \pm 8 \%$, range 0 to $41 \%$, 150 to 1000 m, Mann-Whitney test, p < 0.05; Fig. 2B). Nearly all ostracods (most of which are DVM) examined contained food in their guts, with no significant difference between night and day (Mann-Whitney test, p > 0.05; Fig. 2C). Lucicutia sp. was only present during the day at 150 to $200 \mathrm{~m}$ and $36 \%$ of the individuals analyzed contained food (Fig. 2C). Most of the miscellaneous large calanoid copepods were only present at night in the lower mesopelagic and most of them had food in their guts (Fig. 2C). The proportion of $N$. robustior, $P$. attenuatus, $P$. abdominalis, $P$. xiphias, and miscellaneous ostracods with visible gut content generally decreased with depth, especially at night (Fig. 2A-C).

At K2, the ontogenetic vertically migrating (OVM) copepods Eucalanus bungii, Neocalanus cristatus, and $N$. plumchrus were the dominant mesozooplankton and, at the time of our study, had begun their descent to enter into their diapause phase below $1000 \mathrm{~m}$ (Kobari et al. 2008). The proportion of these individuals with food in their guts decreased with depth down to $300 \mathrm{~m}$, below which these species contained no visible food in their guts (with one exception, a single $N$. plumchrus at 750-1000 m containing food; Fig. 3A). The other taxa analyzed, Metridia pacifica and Pleuromamma quadrangulata (both DVM), Paraeuchaeta spp. and ostracods, all had food in their guts at all depths at which they were abundant (Fig. 3B,C). Nearly all of the DVM zooplankton caught while they were feeding in the epipelagic zone at night had food in their guts, however many still contained food in their guts while at their daytime mesopelagic resident depths as well (Fig. 3B,C).

\section{Cyanobacteria and eukaryotic phytoplankton}

At both ALOHA and K2, a total of 334 individuals were examined under the epifluorescence microscope. Of the 1 to 5 individuals of each target species with gut content at every depth, 50 to $100 \%$ contained 1 to $5 \mu \mathrm{m}$ cyanobacteria and 43 to $100 \%$ included small eukaryotic phytoplankton (Table 2). Considerably more zooplankton at ALOHA contained larger (>5 $\mu \mathrm{m}$ ) cyanobacteria in their guts (82 to $100 \%$ ) than at K2 (36 to $86 \%$, Table 2).

Euchaeta rimana and Neocalanus robustior collected from the epipelagic zone at ALOHA had significantly higher mean concentrations of cyanobacteria in their guts at night $\left(6.8 \times 10^{5} \pm 5.7 \times 10^{5}\right.$ and $3.2 \times 10^{5} \pm 3.8 \times 10^{5}$ cells $\mathrm{mm}^{-3}$, respectively) versus 

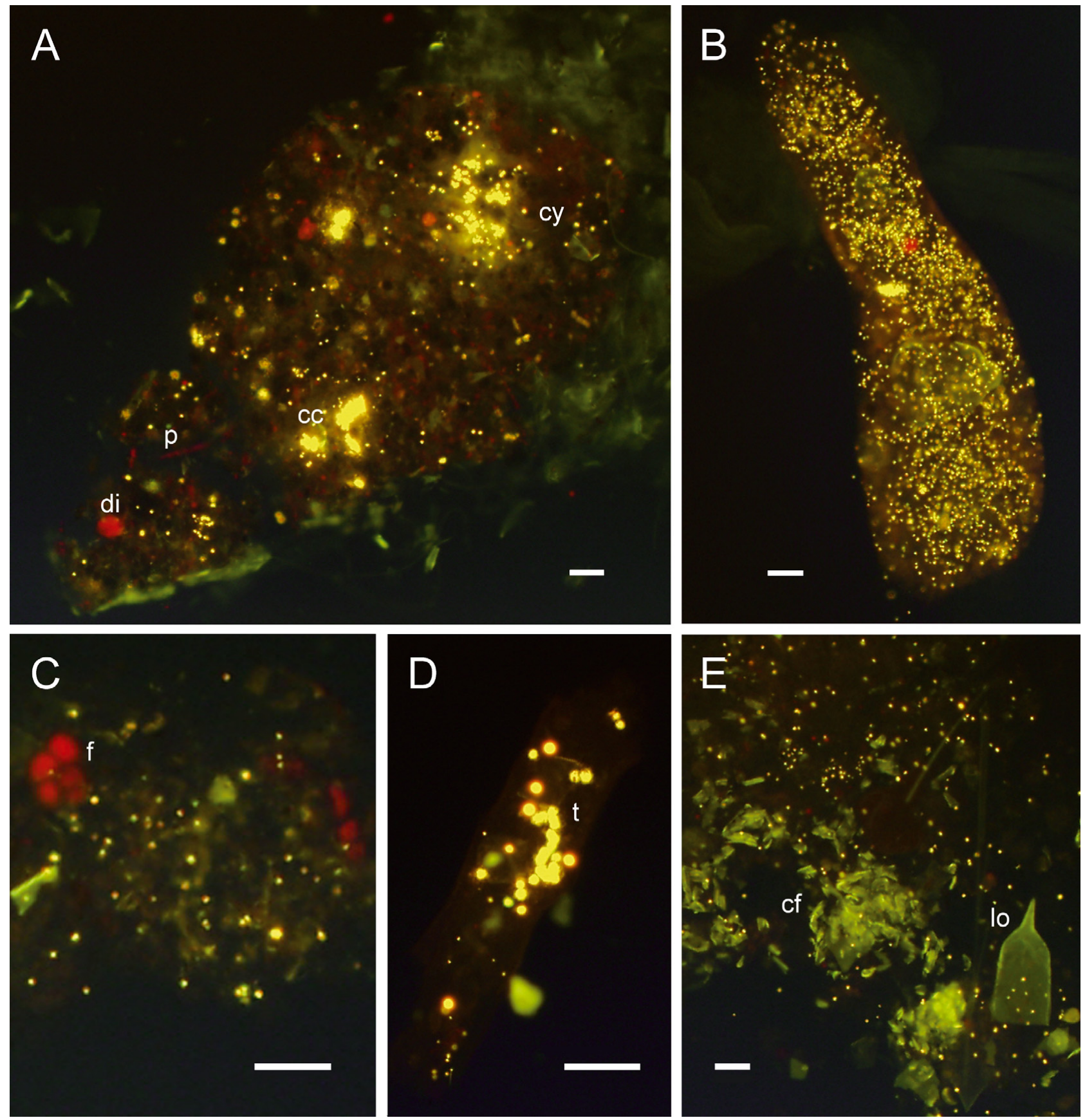

Fig. 1. Zooplankton gut contents as viewed under epifluorescence microscopy. (A) Ostracod from 150 to $200 \mathrm{~m}$ at ALOHA: individual cyanobacteria (cy), cyanobacterial clusters (cc), pennate diatoms (p), and dinoflagellate (di). (B) Metridia pacifica from 0 to $50 \mathrm{~m}$ at K2: high density of cyanobacteria. (C) Pleuromamma quadrangulata from 300 to $400 \mathrm{~m}$ at K2: foraminiferan (f) with red autofluorescing symbionts. (D) Miscellaneous calanoid copepod from 400 to $500 \mathrm{~m}$ at ALOHA: presumed individual cells from Trichodesmium spp. trichome (t). (E) P. quadrangulata from 150 to $200 \mathrm{~m}$ at K2: tintinnid lorica (lo) and crustacean carapace fragments (cf). Scale bar $=20 \mu \mathrm{m}$

day $\left(3.4 \times 10^{4} \pm 2.6 \times 10^{4}\right.$ and $2.6 \times 10^{4} \pm 1.3 \times$ $10^{4}$ cells $\mathrm{mm}^{-3}$, respectively, Mann-Whitney test, $\mathrm{p}<0.05$; Fig. 4A). E. rimana also contained higher concentrations of eukaryotic phytoplankton at night above $150 \mathrm{~m}$ (mean $1.3 \times 10^{4} \pm 7.0 \times 10^{3}$ cells $\mathrm{mm}^{-3}$,
Mann-Whitney test, $\mathrm{p}<0.05$; Fig. 5A). DVM Pleuromamma abdominalis, $P$. piseki/gracilis, and $P$. xiphias had significantly higher concentrations of cyanobacteria in their guts at night in the lower epipelagic zone than during the day in the mesopelagic zone 

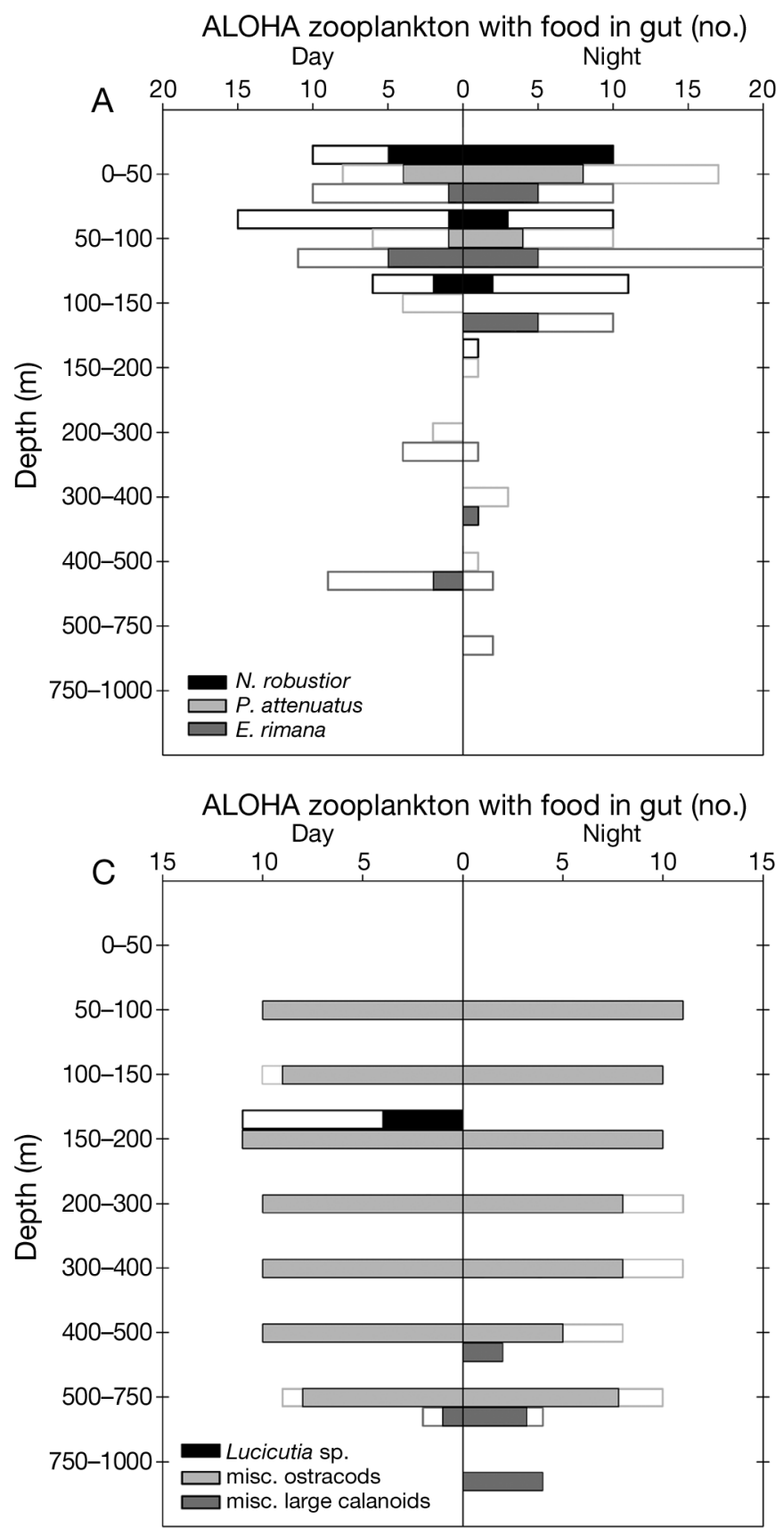

(Mann-Whitney test, $\mathrm{p}<0.05$; Fig. 4B). There was 1 individual $P$. abdominalis at 300 to $400 \mathrm{~m}$ (night) with high cyanobacterial density as well (Fig. 4B). There was no significant difference between night and day for small eukaryotic phytoplankton in DVM species' guts throughout their depth range; however, maximum values were highest in the mesopelagic during the day and epipelagic at night (Fig. 5B). Cyanobacteria density in guts of miscellaneous ostracods, which included migrating species, was at its maximum in the mesopelagic during the day (mean $\pm \mathrm{SE}$
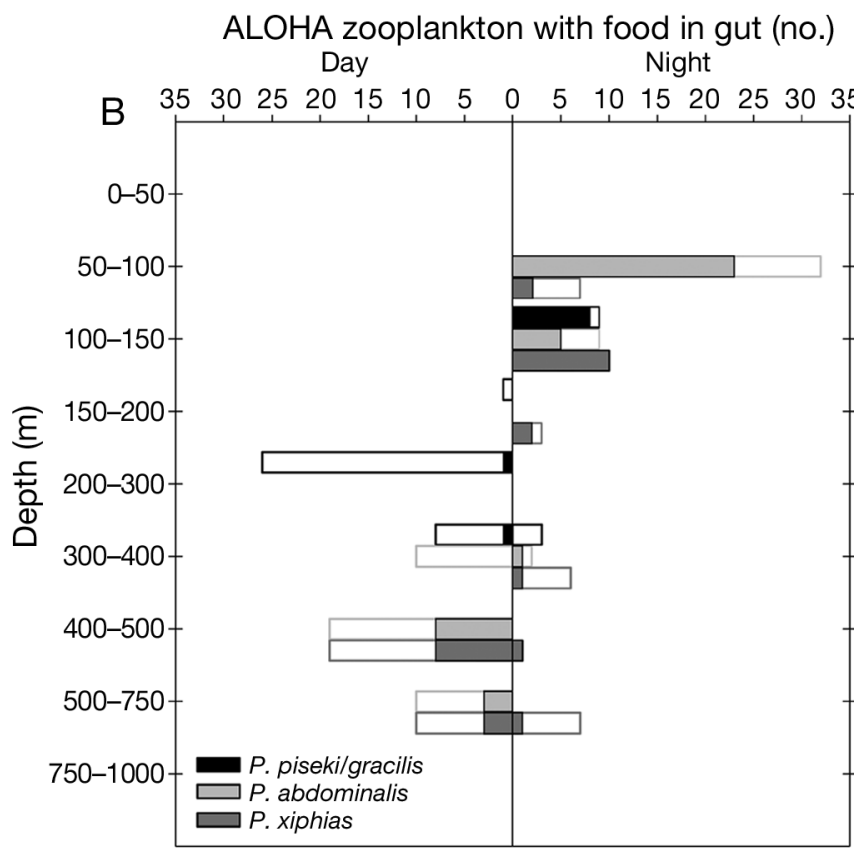

Fig. 2. Zooplankton at each depth interval with food in their gut at ALOHA. (A) Neocalanus robustior, Paraeucalanus attenuatus, and Euchaeta rimana. (B) Pleuromamma piseki/ gracilis, Pleuromamma abdominalis, and Pleuromamma xiphias. (C) Lucicutia sp., miscellaneous (misc.) ostracods, and misc. large copepods. Open bars = total number of each species analyzed. Filled bars $=$ number of each species analyzed containing food in gut

$1.9 \times 10^{5} \pm 1.1 \times 10^{5}$ cells $\mathrm{mm}^{-3}$ ) and epipelagic at night (mean \pm SE $2.1 \times 10^{5} \pm 1.1 \times 10^{5}$ cells $\mathrm{mm}^{-3}$; Fig. 4C). The density of eukaryotic phytoplankton in ostracod guts was variable with depth although generally higher above $300 \mathrm{~m}$ at night (Fig. 5C). The deeper-residing species Lucicutia sp. was only present during the day above $200 \mathrm{~m}$. Densities of cyanobacteria and phytoplankton in the guts of Lucicutia sp. were comparable to those of ostracods (Figs. 4C \& 5C). Miscellaneous large calanoids, generally more carnivorous than the other species (see below), had 


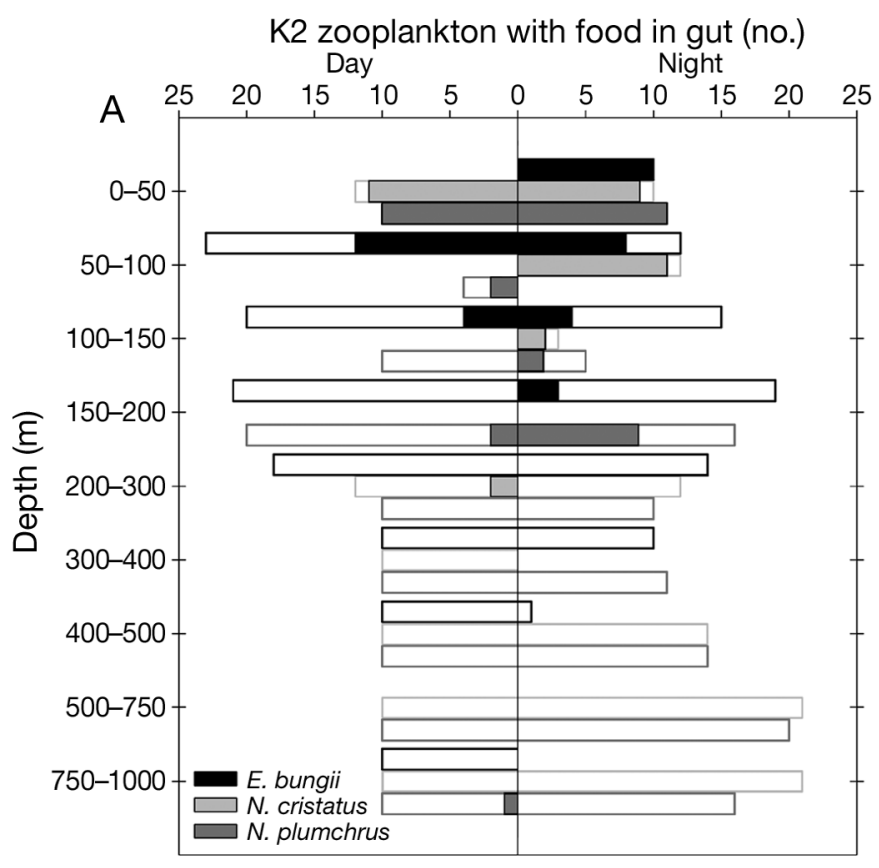

K2 zooplankton with food in gut (no.)



low densities of cyanobacteria and phytoplankton in their guts (Figs. 4C \& 5C). P. xiphias (at 500 to $750 \mathrm{~m}$ ) had the highest mean density of eukaryotic phytoplankton of all the zooplankton sampled at ALOHA $\left(4.4 \times 10^{4} \pm 3.5 \times 10^{4}\right.$ cells $\left.\mathrm{mm}^{-3}\right)$ followed by $N$. robustior at 100 to $150 \mathrm{~m}$ and Lucicutia sp. at 150 to $200 \mathrm{~m}$ (Fig. 5A-C).

At K2, densities of cyanobacteria and eukaryotic phytoplankton in the guts of the OVM copepods Euchaeta bungii, Neocalanus cristatus, and N. plum-

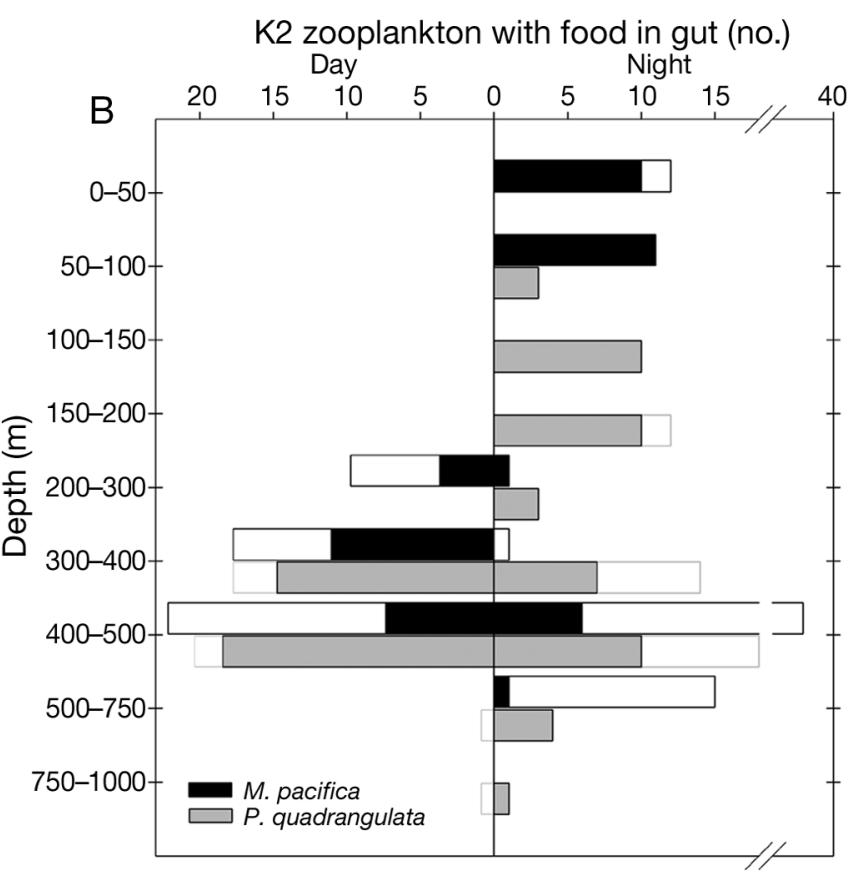

Fig. 3. Zooplankton at each depth interval with food in their gut at K2. (A) Eucalanus bungii, Neocalanus cristatus, and Neocalanus plumchrus. (B) Metridia pacifica and Pleuromamma quadrangulata. (C) Miscellaneous (misc.) ostracods and Paraeuchaeta spp. Open bars = total number of each species analyzed. Filled bars = number of each species analyzed containing food in gut

chrus (only analyzed during the day) were highest in the upper epipelagic and upper mesopelagic zones, with the exception of a single $N$. plumchrus at 750 to $1000 \mathrm{~m}$ that contained high gut densities of cyanobacteria and eukaryotic phytoplankton in its gut (Figs. 6A \& 7A). Gut densities of cyanobacteria and eukaryotic phytoplankton in Paraeuchaeta spp. decreased with depth in the mesopelagic zone (Fig. 6A, Fig. 7A). DVM Metridia pacifica had significantly higher concentrations of cyanobacteria in their guts 

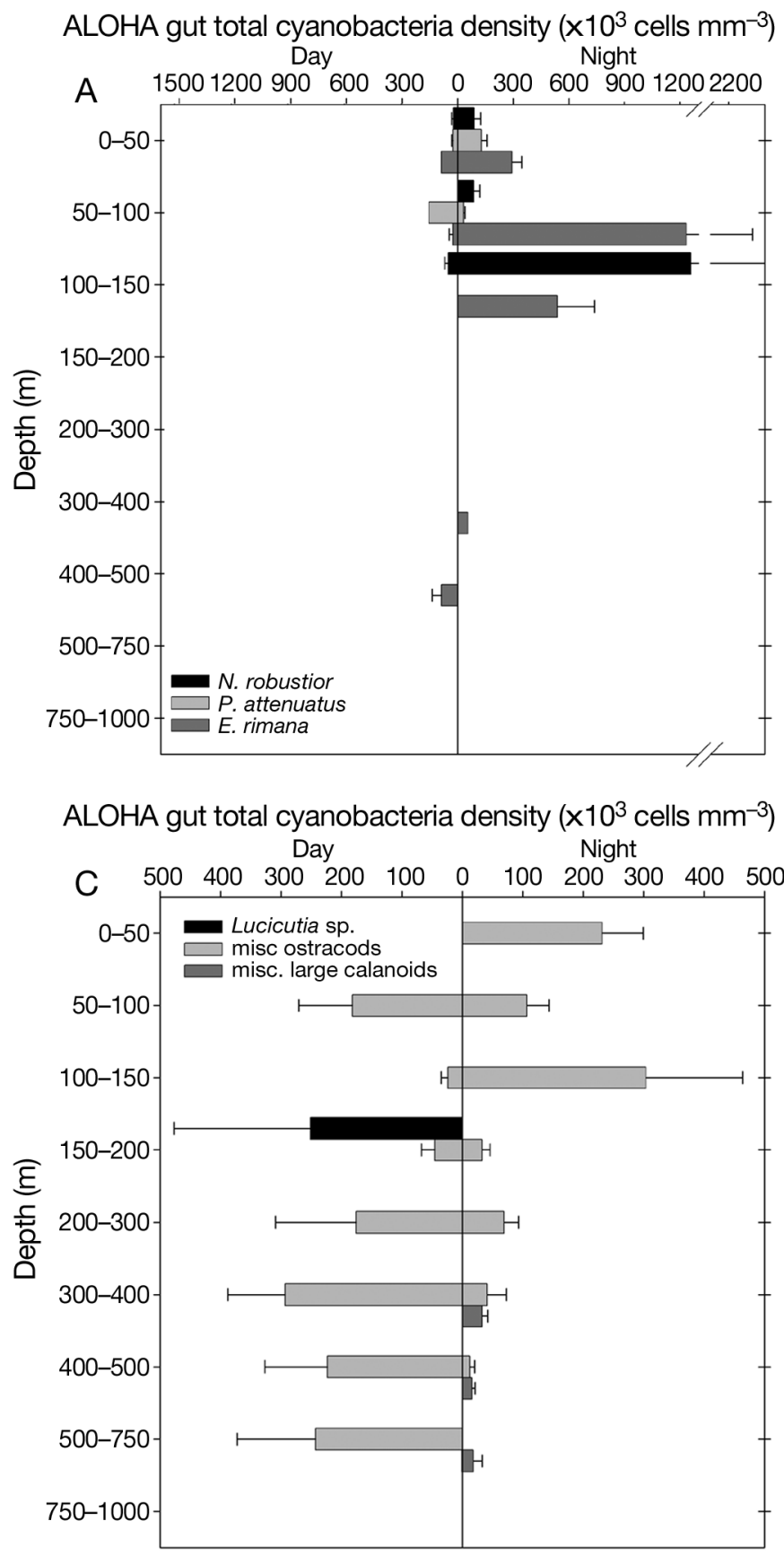

at night in the epipelagic zone $\left(4.8 \times 10^{5} \pm 1.4 \times 10^{5}\right.$ cells $\mathrm{mm}^{-3}$ ) than during the day at their mesopelagic residence depths $\left(3.8 \times 10^{4} \pm 1.5 \times 10^{4}\right.$ cells $\mathrm{mm}^{-3}$, Mann-Whitney test, $\mathrm{p}<0.05$; Fig. 6B). The depth maxima of $M$. pacifica gut eukaryotic phytoplankton density was similar to that of gut cyanobacteria, with the exception of a single individual at 500 to $750 \mathrm{~m}$ with a high eukaryotic phytoplankton density in its gut (Fig. 7B). The diel vertical migrator Pleuromamma quadrangulata concentrated between 300

\section{ALOHA gut total cyanobacteria density $\left(\times 10^{3}\right.$ cells $\left.\mathrm{mm}^{-3}\right)$ Day \\ Night}

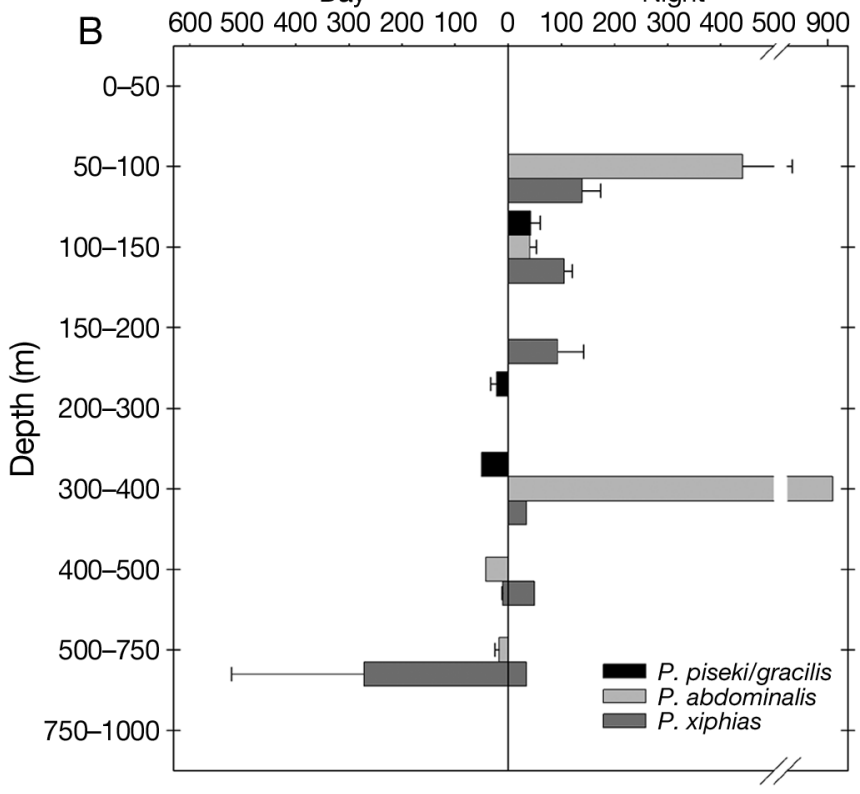

Fig. 4. Cyanobacteria density in zooplankton guts in each depth interval at ALOHA $\left(\times 10^{3}\right.$ cells $\left.\mathrm{mm}^{-3}\right)$. Cyanobacteria density includes both 1 to $5 \mu \mathrm{m}$ cells and $>5 \mu \mathrm{m}$ cells. (A) Neocalanus robustior, Paraeucalanus attenuatus, and Euchaeta rimana. (B) Pleuromamma piseki/gracilis, Pleuromamma abdominalis, and Pleuromamma xiphias. (C) Lucicutia sp., miscellaneous (misc.) ostracods, and misc. large copepods. Values are mean $\pm 1 \mathrm{SE}$ of $\mathrm{n}=1$ to 5 guts per species per depth

and $500 \mathrm{~m}$ during the day and was distributed between 50 and $1000 \mathrm{~m}$ at night. However, the concentration of cyanobacteria and eukaryotic phytoplankton in the guts of $P$. quadrangulata were similar during day and night, with no maximum in the epipelagic zone as seen for M. pacifica (Figs. 6B \& 7B). The maximum density of cyanobacteria in ostracod guts was above $200 \mathrm{~m}$ at night and below $300 \mathrm{~m}$ during the day (Fig. 6B), and gut densities of eukaryotic phytoplankton were maximum at 50 to $100 \mathrm{~m}$ at 
ALOHA gut eukaryotic phytoplankton density $\left(\times 10^{3}\right.$ cells $\left.\mathrm{mm}^{-3}\right)$

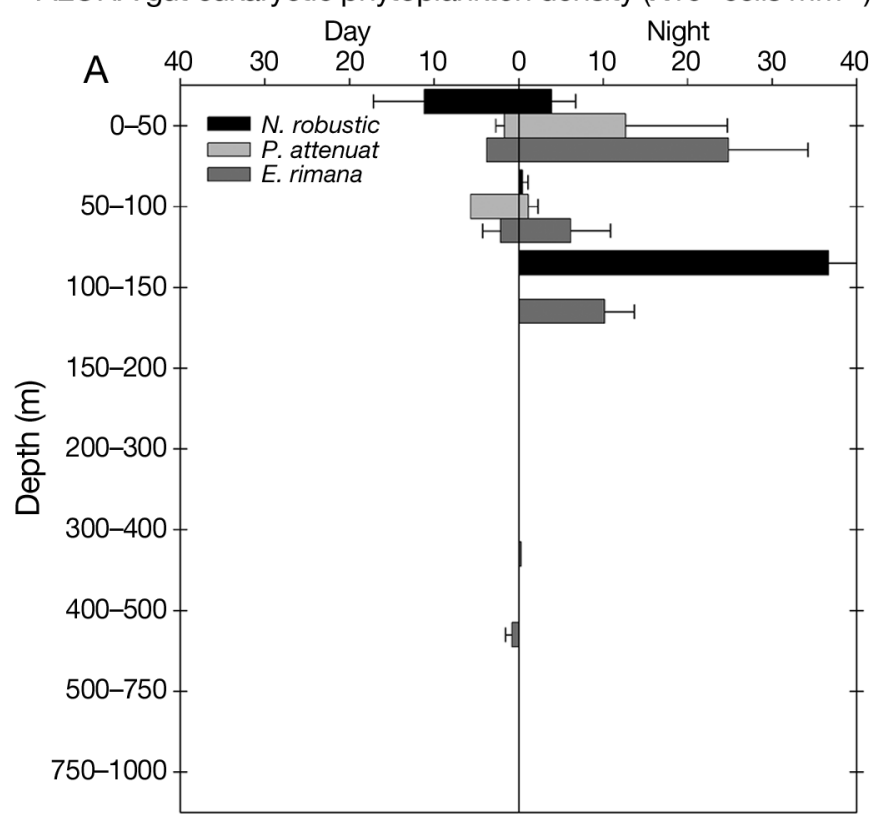

ALOHA gut eukaryotic phytoplankton density $\left(\times 10^{3}\right.$ cells mm $\left.\mathrm{mm}^{-3}\right)$

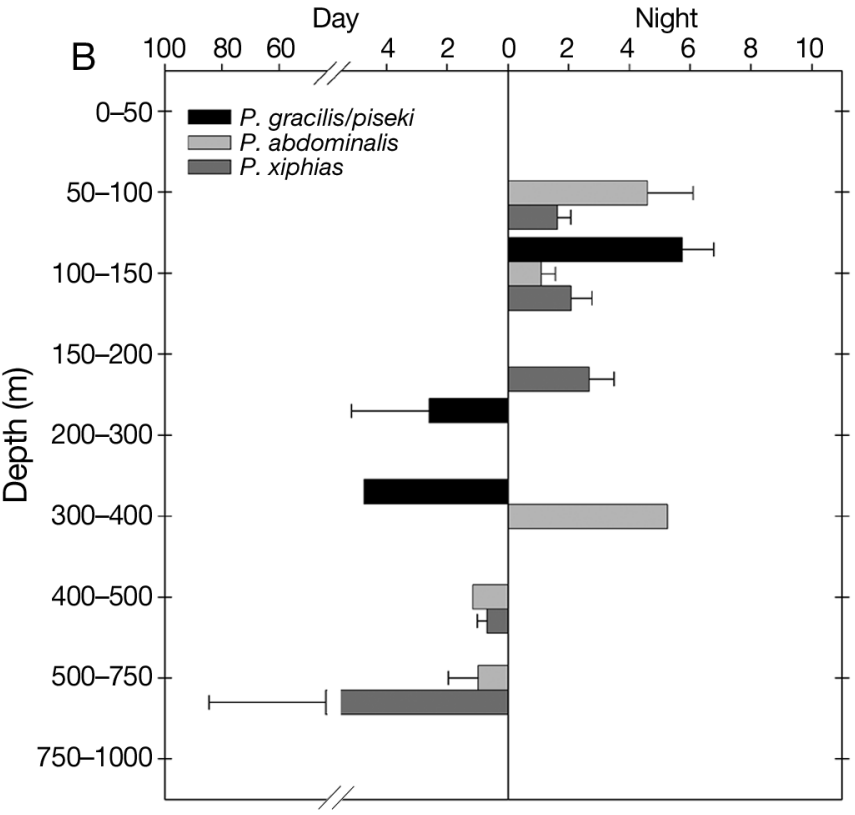

ALOHA gut eukaryotic phytoplankton density $\left(\times 10^{3}\right.$ cells $\left.\mathrm{mm}^{-3}\right)$

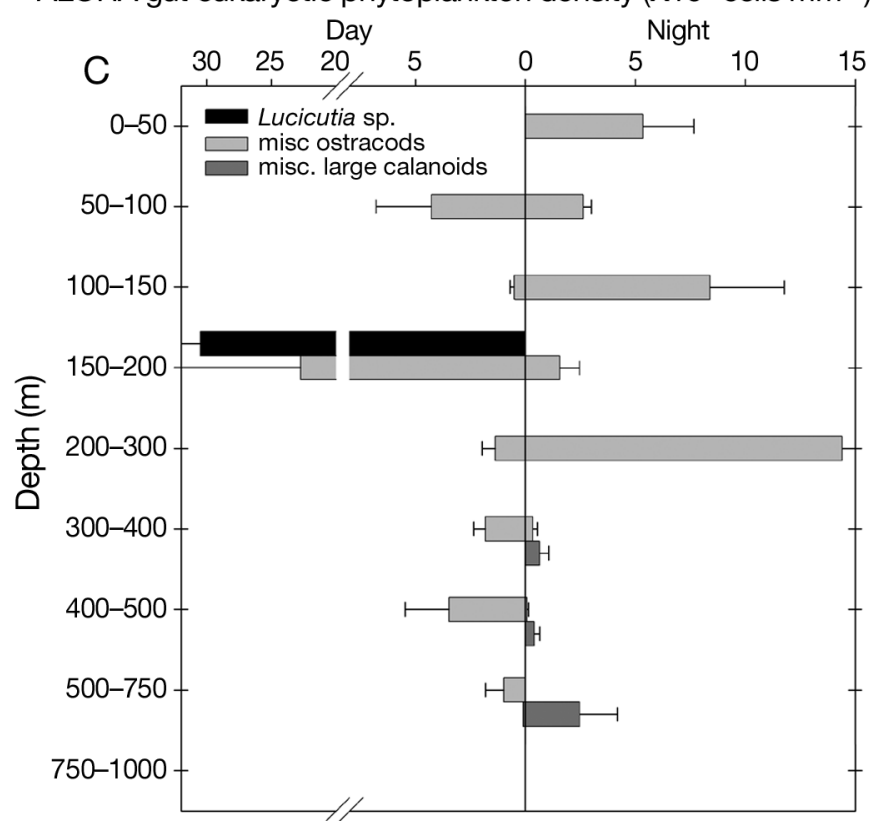

night and 400 to $500 \mathrm{~m}$ during the day (Fig. 7B). $M$. pacifica had the highest day and night gut concentrations of eukaryotic phytoplankton, although all DVM species at K2 had similar concentrations of eukaryotic phytoplankton in their guts throughout their depth of occurrence (Fig. 7B).

Cross comparisons of total gut cyanobacteria and eukaryotic phytoplankton densities for zooplankton collected at ALOHA and K2 resulted in few significant differences between groups (e.g. DVM calanoid
Fig. 5. Eukaryotic phytoplankton density in zooplankton guts in each depth interval at ALOHA $\left(\times 10^{3}\right.$ cells $\left.\mathrm{mm}^{-3}\right)$. (A) Neocalanus robustior, Paraeucalanus attenuatus, and Euchaeta rimana. (B) Pleuromamma piseki/gracilis, Pleuromamma abdominalis, and Pleuromamma xiphias. (C) Lucicutia sp., miscellaneous (misc.) ostracods, and misc. large copepods. Values are mean \pm 1 SE of $n=1$ to 5 guts per species per depth

copepods, ostracods) and depth ranges (e.g. mesopelagic vs. epipelagic), likely due to the large variation in gut cell densities at both sites. The combined day/ night concentrations of cyanobacteria and eukaryotic phytoplankton in the guts of ostracods were both significantly higher at ALOHA $\left(1.4 \times 10^{5} \pm 9.5 \times 10^{4}\right.$ and $5.1 \times 10^{3} \pm 5.7 \times 10^{3}$ cells $\mathrm{mm}^{-3}$, respectively) than $\mathrm{K} 2$ $\left(1.2 \times 10^{5} \pm 1.5 \times 10^{5}\right.$ and $1.2 \times 10^{3} \pm 1.3 \times 10^{3}$ cells $\mathrm{mm}^{-3}$, respectively) throughout their depth range (Mann-Whitney test, $\mathrm{p}<0.05$ ). Also, there were mar- 


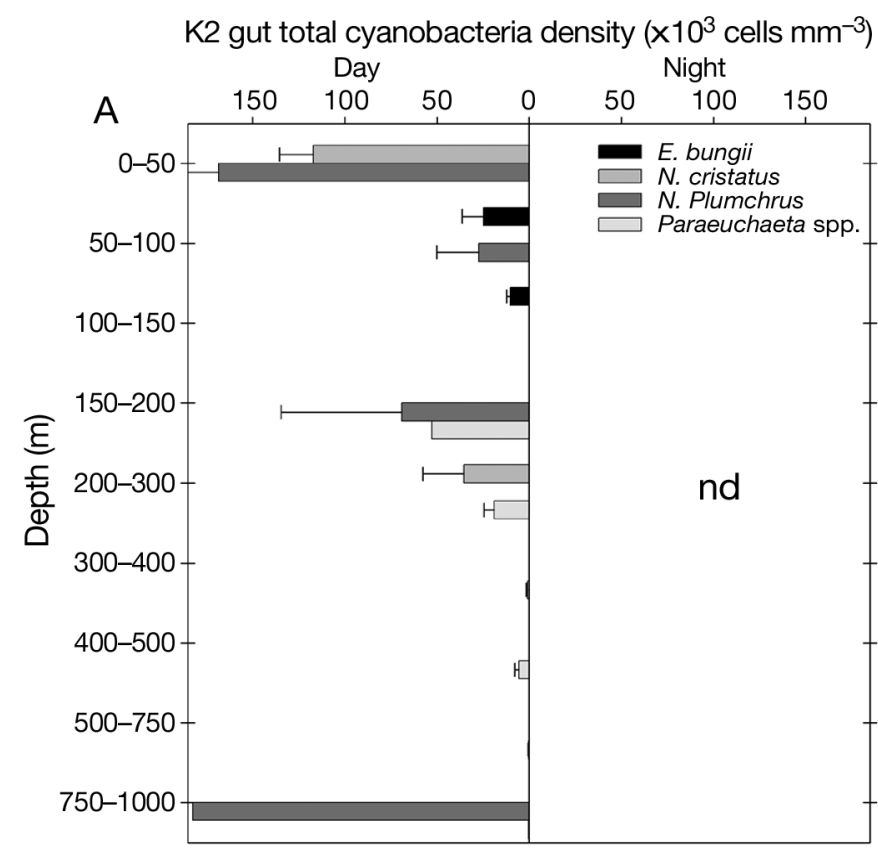
$\mathrm{K} 2$ gut total cyanobacteria density $\left(\times 10^{3}\right.$ cells $\left.\mathrm{mm}^{-3}\right)$ Day
Night

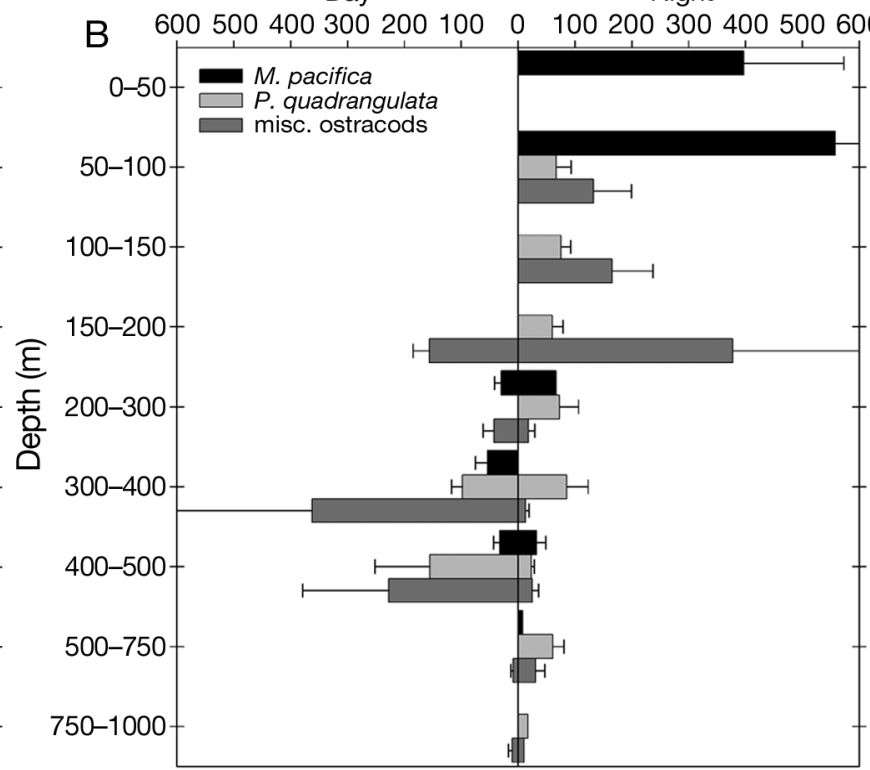

Fig. 6. Cyanobacterial density in zooplankton guts in each depth interval at $\mathrm{K} 2\left(\times 10^{3}\right.$ cells $\left.\mathrm{mm}^{-3}\right)$. Cyanobacteria density includes both 1 to $5 \mu \mathrm{m}$ cells and $>5 \mu \mathrm{m}$ cells. (A) Eucalanus bungii, Neocalanus cristatus, Neocalanus plumchrus, and Paraeuchaeta spp. (B) Metridia pacifica, Pleuromamma quadrangulata, and miscellaneous (misc.) ostracods. Values are mean $\pm 1 \mathrm{SE}$ of $\mathrm{n}=1$ to $5 \mathrm{guts}$ per species per depth. No data (nd) for night in (A)

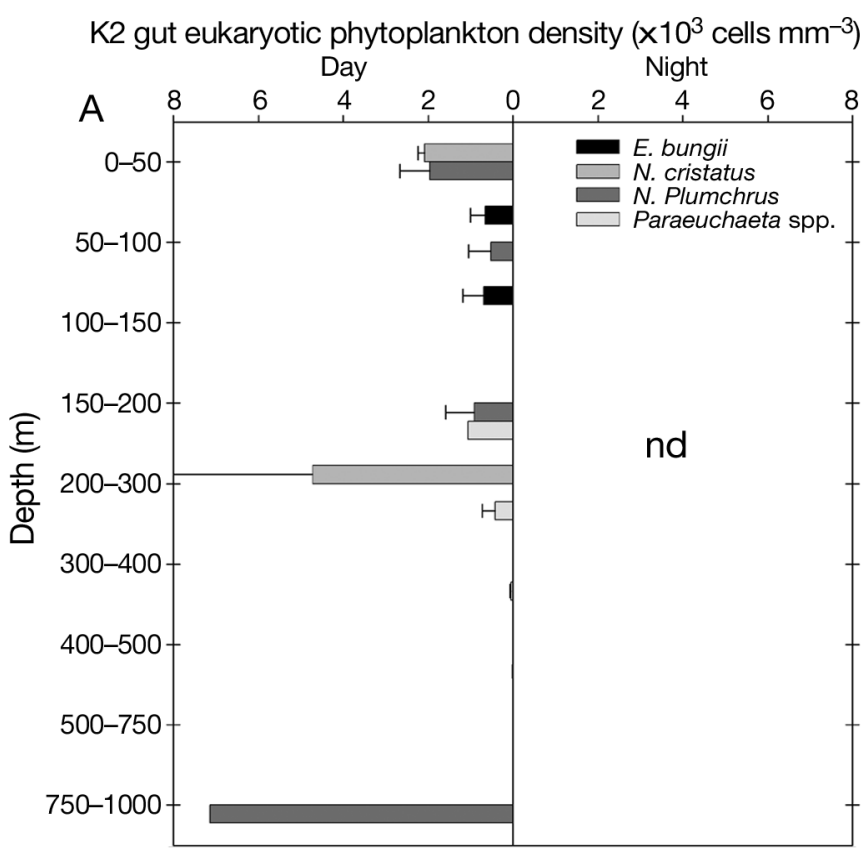

$\mathrm{K} 2$ gut eukaryotic phytoplankton density $\left(\times 10^{3}\right.$ cells $\left.\mathrm{mm}^{-3}\right)$

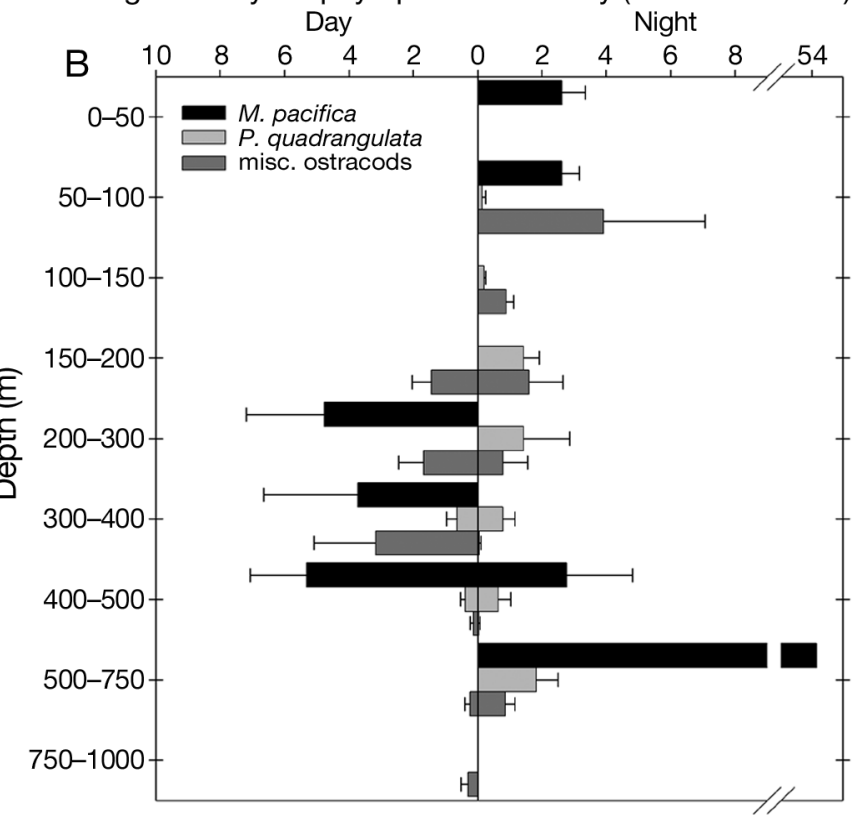

Fig. 7. Eukaryotic phytoplankton density in zooplankton guts in each depth interval at $\mathrm{K} 2\left(\times 10^{3}\right.$ cells $\left.\mathrm{mm}^{-3}\right)$. (A) Eucalanus bungii, Neocalanus cristatus, Neocalanus plumchrus, and Paraeuchaeta spp. (B) Metridia pacifica, Pleuromamma quadrangulata, and miscellaneous (misc.) ostracods. Values are mean \pm 1 standard error of $n=1$ to 5 guts per species per depth. No data (nd) for night in (A)

ginally higher densities of eukaryotic phytoplankton in the guts of zooplankton at mesopelagic depths during the day and all DVM calanoid copepods at ALOHA than at K2.

\section{Other food items present in guts}

All zooplankton gut contents from both ALOHA and K2 had items other than cyanobacteria and eukaryotic 
phytoplankton, with the majority being unidentifiable detrital material. The most abundant identifiable nonautotrophic items included foraminiferans, tintinnid lorica, pieces of carapace from crustaceans, and gastropod shells (Table 3). Other less frequently observed identifiable items included broken diatom tests, radiolarian spines, chaetognath spines, ostracods, cnidarian nematocysts, crustacean nauplii, and zooplankton fecal pellets. Foraminiferans occurred most often in zooplankton guts within the epipelagic (both night and day) and upper mesopelagic during the day at both sites. All gut material from Neocalanus cristatus, Paraeucalanus attenuatus, and Pleuromamma quadrangulata collected in the epipelagic zone (either day or night) contained 1 or more forami- niferans, many of which were still intact (Table 3) and contained photosynthetic symbionts (Fig. 1C). Tintinnid loricae were found consistently and in nearly all target species at $\mathrm{K} 2$ versus in only a few ostracods and Pleuromamma spp. at ALOHA (Table 3).

\section{DISCUSSION}

\section{Zooplankton-mediated picoplankton export via aggregate feeding}

Cyanobacteria and small eukaryotic phytoplankton were present in the guts of all species examined and likely ingested as part of marine snow particles or

Table 3. Percentage of zooplankton gut contents containing other non-phytoplankton material for target species at ALOHA and K2: foraminifera (forams), tintinnid lorica (tintinnids), crustacean carapace material (carapace), and gastropod shells (shells). Data are pooled and presented for the epipelagic (0 to $150 \mathrm{~m})$, upper mesopelagic $(150$ to $500 \mathrm{~m})$, and lower mesopelagic (500 to $1000 \mathrm{~m})$ zones. $0=$ individuals with food in guts, but none of the listed items were present. $-=$ individuals were present at that depth interval but had empty guts. $\square=$ no individuals present at that depth interval. $\mathrm{n}=1$ to $19,{ }^{*} \mathrm{n}<3, \mathrm{nd}=$ no data, misc. = miscellaneous, Lg. = large. See Table 2 for full species names

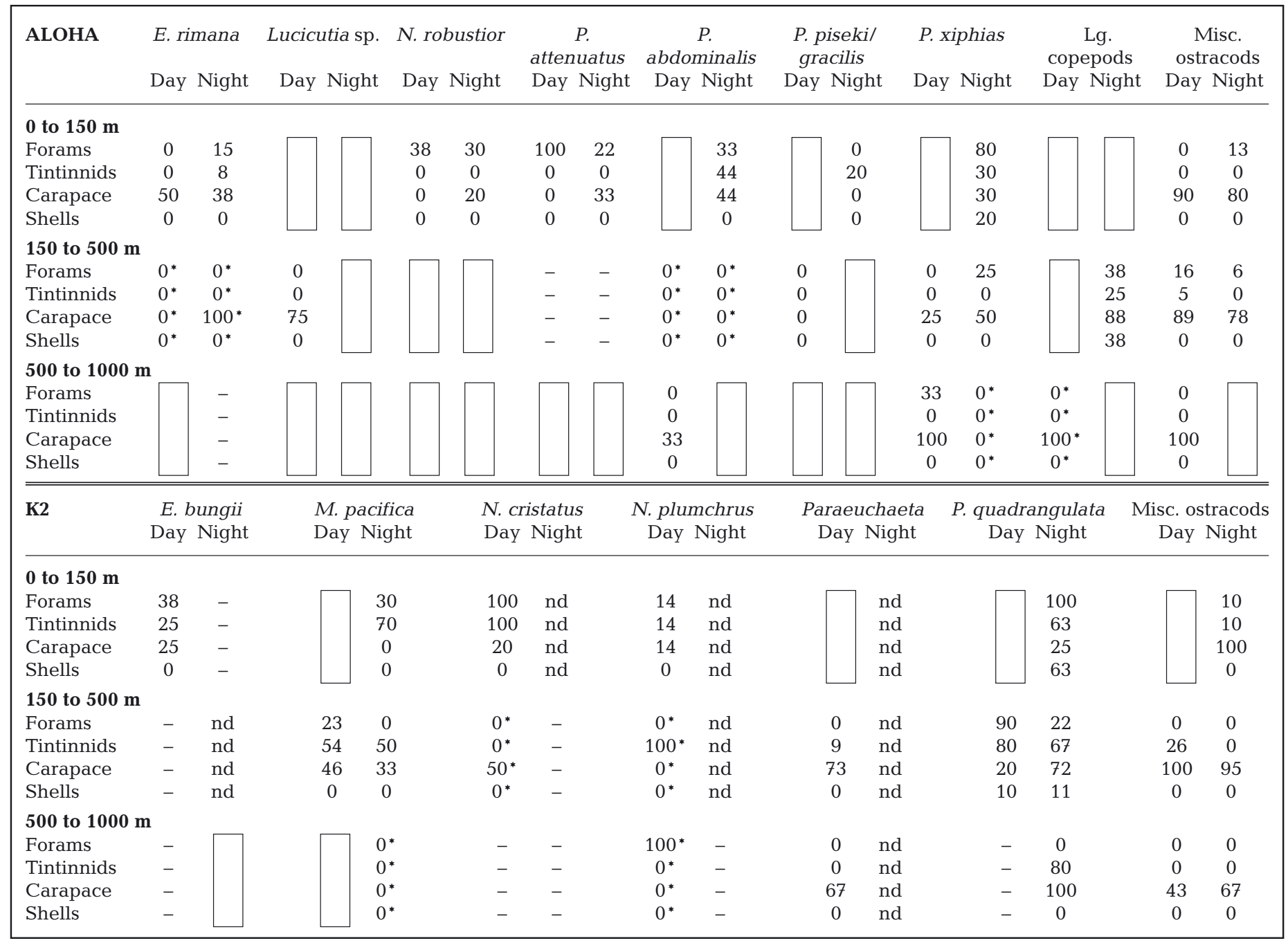


within the guts of other organisms (Nival \& Nival 1976, Silver \& Bruland 1981, Lampitt et al. 1993). For example, the preferred food particle size for Neocalanus cristatus is $>20 \mu \mathrm{m}$ (Liu et al. 2005), considerably larger than the majority of phytoplankton cells we found in their guts. Synechococcus spp. cell abundance in the euphotic zone at $\mathrm{K} 2(0$ to $50 \mathrm{~m})$ and just west of ALOHA in the north Pacific gyre $(0$ to $200 \mathrm{~m}$ ) averages $1.39 \times 10^{4}$ cells $\mathrm{ml}^{-1}$ and $1.7 \times 10^{3}$ cells $\mathrm{ml}^{-1}$, respectively (Zhang et al. 2008). Within marine snow, the concentrations of picoplankton are considerably higher, and this plus their incorporation in aggregates makes cyanobacteria more accessible to grazers than in the surrounding water column (Silver et al. 1986, Lampitt et al. 1993, Waite et al. 2000). In order for the Neocalanus or Pleuromamma species analyzed to ingest the mean number of cyanobacteria measured in their guts directly from individual cells in the water column (given the above Synechococcus spp. abundance), they would need to filter a volume of $1018 \mathrm{ml}$ (K2) and $1176 \mathrm{ml}$ (ALOHA) of seawater. Neocalanus plumchrus and the larger $N$. cristatus, for example, have clearance rates of $\sim 17$ and $\sim 124 \mathrm{ml}$ copepod $^{-1} \mathrm{~h}^{-1}$, respectively (high range, Dagg \& Wyman 1983) and gut passage times of $\sim 1.8$ h (Dagg \& Walser 1987). At these clearance and gut passage rates, obtaining this concentration of gut cyanobacteria via feeding on free-living cells at K2 (which, regardless, are not in the size range readily ingested by these larger copepods, Liu et al. 2005) would be unfeasible (e.g. with a gut passage time of $1.8 \mathrm{~h}$, a clearance rate of $566 \mathrm{ml}$ copepod $^{-1}$ $\mathrm{h}^{-1}$ would be required to filter the $1018 \mathrm{ml}$ noted above). That Neocalanus spp. are unlikely to feed directly on small phytoplankton was also the conclusion of Miller et al. (1991), who suggested that they could not eat enough small cells to support their respiration.

It could be argued that zooplankton feeding on aggregates may actually retard the export of small cells, as there may be some digestion and metabolism of small cells in the gut and therefore only a fraction of the small cells in aggregates would be concentrated in fecal pellets and exported. However, we posit that zooplankton expedite the export of small cells by concentrating aggregate material, some of which may be suspended/non-sinking, or slowly sinking, in their guts and thus repackage the material into faster-sinking particles (Fowler \& Knauer 1986, Turner 2002, Wilson et al. 2008). Fecal pellets, especially from larger zooplankton such as those examined in our study, generally sink faster than aggregates of similar sizes (Small et al. 1979, Turner 2002 and references therein). Therefore, while zooplankton will assimilate some of the aggregate material ingested, they also enhance the flux of small cells, many of which are digestion resistant (see Introduction), within slower-sinking aggregates by concentrating that material into faster sinking fecal pellets. Furthermore, mucous web feeders such as salps and larvaceans can also capture individual picoplankton cells, and export them in rapidly sinking pellets (e.g. Bruland \& Silver 1981).

A potential artifact of any diet study using net capture is that zooplankton are feeding unnaturally while in the nets or buckets. There are a number of reasons why net feeding was not likely to obscure the natural diets of animals in this study (in addition to the preventative steps taken during processing and analyses). Most animals from deeper nets were no longer living by the time of net recovery, and water turbulence in our filtering cod-ends might also be expected to further break apart fragile sinking aggregates as well as inhibit the normal feeding behaviors of zooplankton that did remain alive. While bucket feeding is also a potential artifact for those animals remaining alive, qualitative examination of flocculent material in buckets revealed that flocs contained unidentifiable green fluorescing material that was different from material found in the copepod and ostracod guts. Furthermore, our diet results were consistent with findings of others for several taxa (e.g. Lampitt et al. 1993, Schnetzer \& Steinberg 2002b). Although we were unable to find experimental evidence in the literature for net feeding by copepods or ostracods, euphausiids may feed carnivorously in nets, with larger net mesh sizes reducing this artifact (Hirota 1984). Hopkins (1985) discussed the bias of net feeding in their $1000 \mathrm{~m}$ Antarctic trawls and did find some evidence for it in fish and amphipods, but also concluded, for many of the reasons stated above, that discerned natural diet patterns of most of the species examined were not compromised by net feeding.

\section{Other sources of picoplankton in guts}

There was considerable evidence for carnivorous/ omnivorous feeding by zooplankton at both $\mathrm{K} 2$ and ALOHA, and thus some of the cyanobacteria and other small cells ingested may have originated from inside the guts, or as symbionts, of microzooplankton which were in turn consumed by the larger species examined in this study. For example, foraminifera-containing endosymbiotic eukaryotes and dense clusters of cyanobacteria were present in zooplankton guts at both stations (e.g. Fig. 1A-C). Many K2 zooplankton guts contained tintinnids, which may have also been consuming picoplankton. Ciliated protozoans such as tintinnids and oligotrichs colonize sinking marine snow particles (Silver et al. 1984) and thus could have 
been consumed on these aggregates. Lampitt et al. (1993) considered the presence of tintinnid lorica and cyanobacteria within fecal pellets of the amphipod Themisto compressa evidence of marine snow consumption.

\section{Role of ontogenetic and diel vertical migration in picoplankton export}

Three of the target species at K2, Eucalanus bungii, Neocalanus plumchrus, and $N$. cristatus, are the most abundant calanoid copepod species in the subarctic Pacific Ocean (Mackas et al. 2007, Kobari et al. 2008, Steinberg et al. 2008a). At the time of our sampling, these copepods were beginning their seasonal ontogenetic vertical migration to their bathypelagic overwintering depths. Prior to diapause (when they cease to feed; Kobari \& Ikeda 1999), these copepods are hypothesized to consume eukaryotic phytoplankton, microzooplankton, and cyanobacteria via feeding on marine snow (Dagg 1993, Kobari et al. 2008). Gut contents from our study support this assertion, making actively feeding OVM copepods contributors to export of picoplankton. This is because the OVM species produce large cylindrical fecal pellets at K2 (e.g. Neocalanus spp. have a mean pellet length of $465 \mu \mathrm{m}$ ) which make up to $\sim 79 \%$ of the intact fecal pellet C flux at $150 \mathrm{~m}, \sim 20 \%$ at $300 \mathrm{~m}$, and $~ 38 \%$ at $500 \mathrm{~m}$ (Wilson et al. 2008). OVM fecal matter-derived flux is hypothesized to account for $\sim 15 \%$ of the total $\mathrm{K} 2$ sinking $\mathrm{C}$ flux at $1000 \mathrm{~m}$ (Kobari et al. 2003). Although there was little to no food observed in the guts of these copepods below $300 \mathrm{~m}$, sinking rates of E. bungii, N. plumchrus, and $N$. cristatus fecal pellets range from $\sim 127$ to $\sim 279 \mathrm{~m} \mathrm{~d}^{-1}$ (H. Saito unpubl. data). Therefore, a portion of the OVM zooplankton pellets produced above $300 \mathrm{~m}$ are passively sinking to the lower mesopelagic, exporting a considerable number of cyanobacteria.

Active transport of carbon via diel vertical migration is a key mechanism by which carbon export to the deepsea is enhanced (Longhurst et al. 1990, Zhang \& Dam 1997, Al-Mutairi \& Landry 2001, Schnetzer \& Steinberg 2002a), and is another mechanism by which small phytoplankton cells are exported out of the euphotic zone (Lampitt et al. 1993). The guts of DVM copepods (Pleuromamma piseki/gra- cilis, $P$. abdominalis and $P$ xiphias at ALOHA, and $P$. quadrangulata and Metridia pacifica at K2) and miscellaneous ostracods contained high concentrations of cyanobacteria and small eukaryotic phytoplankton while feeding at night in the epipelagic, as well as at their mesopelagic depths during the day. Gut passage times of DVM zooplankton are longer than their surface-living counterparts, allowing food consumed in the epipelagic to be egested at depth (e.g. Nishida et al. 1991, Schnetzer \& Steinberg 2002a). These 'fresh' fecal pellets produced at depth by migrators will be less decomposed compared to pellets produced in the epipelagic zone, and may be a valuable source of nutrition for mesopelagic biota (Schnetzer \& Steinberg 2002b).

We performed a simple calculation to determine potential active export of cyanobacteria out of the euphotic zone via diel vertical migration (Table 4). We subtracted the number of animals in the surface $150 \mathrm{~m}$ in the night from that in the day, to determine the number of animals migrating, using data only from those size classes (500 to $5000 \mu \mathrm{m})$ for which animals were analyzed for gut content in this study (Steinberg et al. 2008a, D. K. Steinberg unpubl.). We then calculated the average number of cyanobacteria per gut at each station, and assumed that a maximum of 1 gut-load could be actively exported per $24 \mathrm{~h}$ period. Finally, we compared this migrator active flux of cyanobacteria to

Table 4. Potential active export of cyanobacteria out of the euphotic zone via zooplankton diel vertical migration. Data presented are means, with maximum values in parentheses. The migratory density is the number (no.) of zooplankton in the surface $150 \mathrm{~m}$ at night minus that in the day (from Steinberg 2008a, D. K. Steinberg unpubl.). The mean number (no.) of cyanobacteria (cyano) cells per migrator gut was calculated from migrator gut content volumes and gut cell densities in this study. The Synechococcus standing stock at each site is integrated to the depth of the euphotic zone (150 m for ALOHA and $50 \mathrm{~m}$ for K2) (data from Zhang et al. 2008). The passive cyanobacteria flux was measured by sediment traps in a previous study at the VERTEX 5 a site located at $30^{\circ} \mathrm{N}$, $129^{\circ} \mathrm{W}$ in the subtropical Pacific (Silver et al. 1986). See 'Discussion' for further details of calculations

\begin{tabular}{|c|c|c|}
\hline & ALOHA & $\mathrm{K} 2$ \\
\hline Migrator density (no. $\mathrm{m}^{-2}$ ) & $8132(24820)$ & $24230(50638)$ \\
\hline Mean no. cyano per migrator gut & 3319 & 9970 \\
\hline $\begin{array}{l}\text { Migratory active cyano flux } \\
\left(\text { cells } \mathrm{m}^{-2} \mathrm{~d}^{-1}\right)\end{array}$ & $2.7 \times 10^{7}\left(8.2 \times 10^{7}\right)$ & $1.6 \times 10^{8}\left(5.1 \times 10^{8}\right)$ \\
\hline $\begin{array}{l}\text { Synechococcus standing stock } \\
\text { in euphotic zone (cells } \mathrm{m}^{-2} \text { ) }\end{array}$ & $2.6 \times 10^{11}$ & $7.0 \times 10^{11}$ \\
\hline $\begin{array}{l}\text { Proportion of cyano standing } \\
\text { stock removed by migrators (\%) }\end{array}$ & $0.01(0.03)$ & $0.01(0.07)$ \\
\hline $\begin{array}{l}\text { VERTEX 5a cyano flux out of } \\
\text { euphotic zone (cells } \mathrm{m}^{-2} \mathrm{~d}^{-1} \text { ) }\end{array}$ & $5.2 \times 10^{7}$ & \\
\hline $\begin{array}{l}\text { Active cyano flux / } \\
\text { passive cyano flux (\%) }\end{array}$ & $51.5(158.4)$ & \\
\hline
\end{tabular}


the standing stock of Synechococcus spp. in the euphotic zone (Zhang et al. 2008), and to the flux of cyanobacteria measured by sediment traps. We did not have the latter data for VERTIGO, but were able to compare our ALOHA diel migratory flux to the flux of cyanobacteria leaving the euphotic zone $(150 \mathrm{~m})$ as measured by sediment traps at the VERTEX 5a site located at $30^{\circ} \mathrm{N}, 129^{\circ} \mathrm{W}$ in the subtropical Pacific $(7.5 \times$ $10^{7}$ cells m ${ }^{-2} \mathrm{~d}^{-1}$, from Table 2 in Silver et al. 1986). The active transport of cyanobacteria via diel vertical migration was an insignificant fraction of the euphotic zone standing stock at either station $(<0.07 \%)$, but was equal to an average of $51.5 \%$, and a maximum of $158.4 \%$, of the flux of small cells as measured by sediment traps in the subtropical Pacific (Table 4). Thus, diel migrators can enhance picoplankton export over what is passively sinking. The transport by diel vertical migration is, of course, only a fraction of the mesozooplankton-mediated export, as zooplankton fecal pellets containing picoplankton are also passively sinking out of the euphotic zone (the contribution of which we did not have sufficient data to calculate).

\section{Consumption of diazotrophs and implications for transfer in marine food webs and export of new nitrogen}

There is recent evidence of zooplankton ingestion of $\mathrm{N}_{2}$-fixing cyanobacteria and the importance of small $\mathrm{N}_{2}$ fixers to nitrogen budgets in warm oligotrophic waters (Montoya et al. 2002, Carpenter \& Capone 2008). The higher percentages of $>5 \mu \mathrm{m}$ cyanobacterial cells in zooplankton guts at ALOHA are likely to be individual Trichodesmium spp. trichomes and Richelia spp. (endosymbiotes in diatoms). Although not likely to be directly grazing on Trichodesmium spp. colonies at ALOHA (i.e. few zooplankton are known to consume Trichodesmium spp., which is thought to be noxious or harmful, O'Neil \& Roman 1994), zooplankton may be consuming trichomes or pieces of Trichodesmium spp. within aggregates, as the density of $>5 \mu \mathrm{m}$ cyanobacteria in their guts was relatively low. In addition, newly discovered small, unicellular diazotrophs may comprise some of the 3 to $5 \mu \mathrm{m}$ cells in guts at ALOHA (Zehr et al. 2001, 2007, Montoya et al. 2004). These unicellular $\mathrm{N}_{2}$-fixing bacteria are broadly distributed in the warm, oligotrophic Pacific Ocean (Zehr et al. 2001, 2007, Montoya et al. 2004, 2007, Church et al. 2008) and could also be consumed within aggregates. Thus, in the subtropics, the indirect grazing on these diazotrophs by particle-feeding zooplankton could be an important pathway by which new nitrogen is exported to depth.

\section{CONCLUSIONS}

This study provides further evidence that mesozooplankton grazing on aggregates is a pathway by which vertical flux of picoplankton can be enhanced. Picoplanktonic cyanobacteria were present in nearly all gut contents analyzed, indicating that consumption of detritus is an important means by which both epipelagic and mesopelagic zooplankton at K2 and ALOHA obtain their nutrition, and that subsequent egestion of this material as fecal pellets enhances passive vertical export of small cells (some of which are likely diazotrophs). DVM or OVM zooplankton are also important contributors to the active flux of picoplankton out of the epipelagic at K2 and ALOHA. While ALOHA and K2 are contrasting environments with different phytoplankton and zooplankton community structures, mesopelagic zooplankton at both sites increase the transfer efficiency of picoplankton carbon to the deep sea.

Acknowledgements. Our thanks to the captains and crews of the RV 'Kilo Moana' and RV 'Roger Revelle' for their assistance during the VERTIGO cruises. Thanks to K. Buesseler for his leadership in VERTIGO and for his help at sea. We are very grateful to $\mathrm{M}$. Silver and S. Coale for their advice on epifluorescence microscopy of picoplankton, J. Cope for zooplankton species identification and sample processing, and $\mathrm{T}$. Kobari for help with sample collection and processing at sea. Thanks to W. Coats for tintinnid identification and J. Dreyer and W. Smith for microscope use. This study was supported by a grant from the U.S. National Science Foundation NSF OCE-0324402 (Biological Oceanography) to D.K.S. This paper is Contribution No. 3089 of the Virginia Institute of Marine Science.

\section{LITERATURE CITED}

Al-Mutairi H, Landry MR (2001) Active export of carbon and nitrogen at Station ALOHA by diel migrant zooplankton. Deep-Sea Res II 48:2083-2103

Alldredge AL, Silver MW (1988) Characteristics, dynamics and significance of marine snow. Prog Oceanogr 20:41-82

Angel MV (1989) Does mesopelagic biology affect the vertical flux? In: Berger WH, Smetacek V, Wefer G (eds) Productivity of the ocean: present and past. John Wiley and Sons, New York, NY, p 155-173

Boyd PW, Gall MP, Silver MW, Coale SL, Bidigare RR, Bishop JK (2008) Quantifying the surface-subsurface biogeochemical coupling during the VERTIGO ALOHA and K2 studies. Deep-Sea Res II 55:1578-1593

Bruland KW, Silver MW (1981) Sinking rates of fecal pellets from gelatinous zooplankton (salps, pteropods, doliolids). Mar Biol 63:295-300

Buesseler KO, Lamborg CH, Boyd PW, Lam PJ and others (2007) Revisiting carbon flux through the ocean's twilight zone. Science 316:567-570

Buesseler KO, Bidigare RR, Bishop JK, Boyd PW and others (2008) What we know from VERTIGO (VERtical Transport In the Global Ocean). Deep-Sea Res II 55:1522-1539 
Carpenter EJ, Capone DG (2008) Nitrogen fixation in the marine environment. In: Capone DG, Bronk DA, Mullholland MR, Carpenter EJ (eds) Nitrogen in the marine environment, 2nd edn. Academic Press, Boston, p 141-198

Church MJ, Björkman KM, Karl DM, Saito M, Zehr JP (2008) Regional distributions of nitrogen-fixing bacteria in the Pacific Ocean. Limnol Oceanogr 53:63-77

Dagg MJ (1993) Sinking particles as a possible source of nutrition for the large calanoid copepod Neocalanus cristatus in the subarctic Pacific Ocean. Deep-Sea Res I 40: 1431-1445

Dagg MJ, Walser WE Jr. (1987) Ingestion, gut passage, and egestion by the copepod Neocalanus plumchrus in the laboratory and in the subarctic Pacific Ocean. Limnol Oceanogr 32:178-188

$>$ Dagg MJ, Wyman KD (1983) Natural ingestion rates of the copepods Neocalanus plumchrus and N. cristatus calculated from gut contents. Mar Ecol Prog Ser 13:37-46

Dilling L, Brzezinski MA (2004) Quantifying marine snow as a food choice for zooplankton using stable silicon isotope tracers. J Plankton Res 26:1105-1114

Dilling L, Wilson J, Steinberg DK, Alldredge AL (1998) Feeding by the euphausiid Euphausia pacifica and the copepod Calanus pacificus on marine snow. Mar Ecol Prog Ser 170: 189-201

Elskens M, Brion N, Buesseler KO, Van Mooy BAS and others (2008) Primary, new and export production in the NW Pacific subarctic gyre during the VERTIGO K2 experiments. Deep-Sea Res II 55:1594-1604

Fowler SW, Knauer GA (1986) Role of large particles in the transport of elements and organic compounds through the oceanic water column. Prog Oceanogr 16:147-194

Hirota Y (1984) Feeding of eupausiids in the plankton net after capture. Bull Plankton Soc Jpn 31:53-60

Hopkins TL (1985) Food web of an Antarctic midwater ecosystem. Mar Biol 89:197-212

Irigoien X (1998) Gut clearance rate constant, temperature and initial gut contents: a review. J Plankton Res 20: 997-1003

Jackson JA (1993) Flux feeding as a mechanism for zooplankton grazing and its implications for vertical particulate flux. Limnol Oceanogr 38:1328-1331

Kobari T, Ikeda T (1999) Vertical distribution, population structure and life cycle of Neocalanus cristatus (Crustacea: Copepoda) in the Oyashio region, with notes on its regional variations. Mar Biol 134:683-696

Kobari T, Shinada A, Tsuda A (2003) Functional roles of interzonal migrating mesozooplankton in the western subarctic Pacific. Prog Oceanogr 57:279-298

Kobari T, Steinberg DK, Ueda A, Tsuda A, Silver MW, Kitamura M (2008) Impacts of ontogenetically migrating copepods on downward carbon flux in the western subarctic Pacific Ocean. Deep-Sea Res II 55:1648-1660

Kosobokova KN, Hirche HJ, Scherzinger T (2002) Feeding ecology of Spinocalanus antarcticus, a mesopelagic copepod with a looped gut. Mar Biol 141:503-511

Lamborg $\mathrm{CH}$, Buesseler $\mathrm{KO}$, Valdez J, Bertrand $\mathrm{CH}$ and others (2008) The flux of bio- and lithogenic material associated with sinking particles in the mesopelagic 'twilight zone' of the northwest and North Central Pacific Ocean. Deep-Sea Res II 55:1540-1563

- Lampitt RS (1992) The contribution of deep-sea macroplankton to organic remineralization: results from sediment trap and zooplankton studies over the Madeira Abyssal Plain. Deep-Sea Res 39:221-233

> Lampitt RS, Wishner KF, Turley CM, Angel MV (1993) Marine snow studies in the Northeast Atlantic Ocean: distribution, composition and role as a food source for migrating plankton. Mar Biol 116:689-702

Liu H, Dagg MJ, Strom S (2005) Grazing by the calanoid copepod Neocalanus cristatus on the microbial food web in the coastal Gulf of Alaska. J Plankton Res 27:647-662

Lochte K, Turley CM (1988) Bacteria and cyanobacteria associated with phytodetritus in the deep sea. Nature 333: $67-69$

Longhurst AR, Bedo AW, Harrison WG, Head EJH, Sameoto DD (1990) Vertical flux of respiratory carbon by oceanic and diel migrant biota. Deep-Sea Res 37:685-694

> Mackas DL, Batten S, Trudel M (2007) Effects on zooplankton of a warmer ocean: Recent evidence from the Northeast Pacific. Prog Oceanogr 75:223-252

Miller CB, Frost BW, Wheeler PA, Landry MR, Welschmeyer N, Powell TM (1991) Ecological dynamics in the subarctic Pacific, a possibly iron-limited ecosystem. Limnol Oceanogr 36:1600-1615

Montoya JP, Carpenter EJ, Capone DG (2002) Nitrogen fixation and nitrogen isotope abundances in zooplankton of the oligotrophic North Atlantic. Limnol Oceanogr 47: 1617-1628

> Montoya JP, Holl CM, Zehr JP, Hansen A, Villareal TA, Capone DG (2004) High rates of $\mathrm{N}_{2}$ fixation by unicellular diazotrophs in the oligotrophic Pacific Ocean. Nature 430: 1027-1031

> Montoya JP, Voss M, Capone DG (2007) Spatial variation in $\mathrm{N}_{2}$-fixation rate and diazotroph activity in the Tropical Atlantic. Biogeosciences 4:369-376

Nishida S, Oh B-C, Nemoto T (1991) Midgut structure and food habits of the mesopelagic copepods Lophothrix frontalis and Scottocalanus securifrons. Bull Plankton Soc Jpn (Spec Vol):527-534

$>$ Nival P, Nival S (1976) Particle retention efficiencies of an herbivorous copepod, Acartia clausi (adult and copepodite stages): effects on grazing. Limnol Oceanogr 21:24-38

Noji TT (1991) The influence of macrozooplankton on vertical particle flux. Sarsia 76:1-9

> O'Neil JM, Roman MR (1994) Ingestion of the cyanobacterium Trichodesmium spp. by pelagic harpacticoid copepods, Macrosetella, Miracia and Oculosetella. Hydrobiologia 292-293:235-240

Pfannkuche O, Lochte K (1993) Open ocean pelago-benthic coupling: cyanobacteria as tracers of sedimenting salp faeces. Deep-Sea Res I 40:727-737

- Richardson TL, Jackson GA (2007) Small phytoplankton and carbon export from the surface ocean. Science 315: 838-840

> Richardson TL, Jackson GA, Ducklow HW, Roman MR (2004) Carbon fluxes through food webs of the eastern equatorial Pacific: an inverse approach. Deep-Sea Res I 51: 1245-1274

Sarnelle O (1999) Zooplankton effects on vertical particulate flux: Testable models and experimental results. Limnol Oceanogr 44:357-370

> Schnetzer A, Steinberg DK (2002a) Active transport of particulate organic carbon and nitrogen by vertically migrating zooplankton in the Sargasso Sea. Mar Ecol Prog Ser 234: 71-84

Schnetzer A, Steinberg DK (2002b) Natural diets of vertically migrating zooplankton in the Sargasso Sea. Mar Biol 141: 89-99

Silver MW, Alldredge AL (1981) Bathypelagic marine snow: deep-sea algal and detrital communities. J Mar Res 39:501-530

Silver MW, Bruland KW (1981) Differential feeding and fecal pellet composition of salps and pteropods, and the possi- 
ble origin of the deep-water flora and olive-green 'cells'. Mar Biol 62:263-273

Silver MW, Gowing MM, Brownlee DC, Corliss JO (1984) Ciliated protozoa associated with oceanic sinking detritus. Nature 309:246-248

Silver MW, Gowing MM, Davoll PJ (1986) The association of photosynthetic picoplankton and ultraplankton with pelagic detritus through the water column $(0-2000 \mathrm{~m})$. Can Bull Fish Aquat Sci 214:311-341

Small LF, Fowler SW, Unlu MY (1979) Sinking rates of natural copepod fecal pellets. Mar Biol 51:233-241

Steinberg DK (1995) Diet of copepods (Scopalatum vorax) associated with mesopelagic detritus (giant larvacean houses) in Monterey Bay, California. Mar Biol 122: 571-584

Steinberg DK, Calson CA, Bates NR, Goldthwait SA, Madin LP, Michaels AF (2000) Zooplankton vertical migration and the active transport of dissolved organic and inorganic carbon in the Sargasso Sea. Deep-Sea Res I 47: $137-158$

Steinberg DK, Cope JS, Wilson SE, Kobari T (2008a) A comparison of mesopelagic mesozooplankton community structure in the subtropical and subarctic North Pacifc Ocean. Deep-Sea Res II 55:1615-1635

Steinberg DK, Van Mooy B, Buesseler KO, Boyd PW, Kobari T, Karl DM (2008b) Bacterial vs. zooplankton control of sinking particle flux in the ocean's twilight zone. Limnol Oceanogr 53:1327-1338

Turner JT (2002) Zooplankton fecal pellets, marine snow and sinking phytoplankton blooms. Aquat Microb Ecol 27:57-102

Uttal L, Buck KR (1996) Dietary study of the midwater poly-

Editorial responsibility: William Peterson,

Newport, Oregon, USA chaete Poebius meseres in Monterey Bay, California. Mar Biol 125:333-343

Waite AM, Safi KA, Hall JA, Nodder SD (2000) Mass sedimentation of picoplankton embedded in organic aggregates. Limnol Oceanogr 45:87-97

Wiebe $\mathrm{PH}$, Morton AW, Bradley AM, Backus RH and others (1985) New developments in the MOCNESS, an apparatus for sampling zooplankton and micronekton. Mar Biol 87:313-323

> Wilson SE, Steinberg DK, Buesseler KO (2008) Changes in fecal pellet characteristics with depth as indicators of zooplankton repackaging of particles in the mesopelagic zone of the subtropical and subarctic North Pacific Ocean. Deep-Sea Res II 55:1636-1647

Wilson SE, Steinberg DK, Chu FL, Bishop JKB (2010) Feeding ecology of mesopelagic zooplankton of the subtropical and subarctic North Pacific Ocean determined with fatty acid biomarkers. Deep-Sea Res I, in press, doi: 10.1016/ j.dsr.2010.07.005

Zehr JP, Waterbury JB, Turner PJ, Montoya JP and others (2001) Unicellular cyanobacteria fix $\mathrm{N}_{2}$ in the subtropical North Pacific Ocean. Nature 412:635-638

Zehr JP, Montoya JP, Jenkins BD, Hewson I and others (2007) Experiments linking nitrogenase gene expression to nitrogen fixation in the North Pacific subtropical gyre. Limnol Oceanogr 52:169-183

Zhang X, Dam HG (1997) Downward export of carbon by diel migrant mesozooplankton in the central equatorial Pacific. Deep-Sea Res II 44:2191-2202

Zhang Y, Jiao NZ, Hong N (2008) Comparative study of picoplankton biomass and community structure in different provinces from subarctic to subtropical oceans. DeepSea Res II 55:1605-1614

Submitted: April 2, 2009; Accepted: May 4, 2010

Proofs received from author(s): July 30, 2010 